\title{
Removal of Pb from Water: The Effectiveness of Gypsum and Calcite Mixtures
}

\author{
Ana Roza Llera ${ }^{1}$ (D), Amalia Jimenez ${ }^{1, *(\mathbb{D})}$ and Lurdes Fernández-Díaz ${ }^{2,3}$ (D) \\ 1 Department of Geology, University of Oviedo, 33005 Oviedo, Spain; rozaana@uniovi.es \\ 2 Dpto. Cristalografía y Mineralogía, Universidad Complutense de Madrid, José Antonio Novais, 2, \\ 28040 Madrid, Spain; ishtar@ucm.es \\ 3 Instituto de Geociencias (UCM, CSIC), Ciudad Universitaria, 28040 Madrid, Spain \\ * Correspondence: amjimenez@uniovi.es
}

check for updates

Citation: Roza Llera, A.; Jimenez, A.; Fernández-Díaz, L. Removal of $\mathrm{Pb}$ from Water: The Effectiveness of Gypsum and Calcite Mixtures. Minerals 2021, 11, 66. https:// doi.org/ 10.3390/min11010066

Received: 11 November 2020 Accepted: 31 December 2020 Published: 11 January 2021

Publisher's Note: MDPI stays neutral with regard to jurisdictional clai$\mathrm{ms}$ in published maps and institutional affiliations.

Copyright: (C) 2021 by the authors. Licensee MDPI, Basel, Switzerland. This article is an open access article distributed under the terms and conditions of the Creative Commons Attribution (CC BY) license (https:// creativecommons.org/licenses/by/ $4.0 /)$.

\begin{abstract}
Anthropogenic lead pollution is an environmental problem that threatens the quality of soils and waters and endangers living organisms in numerous surface and subsurface habitats. Lead coprecipitation on mineral surfaces through dissolution-recrystallization processes has long-term effects on lead bioavailability. Gypsum and calcite are among the most abundant and reactive rock forming minerals present in numerous geological settings. In this work, we studied the interaction of slightly acidic $\left(\mathrm{pH}_{\mathrm{i}}=5.5\right) \mathrm{Pb}$-bearing aqueous solutions $\left([\mathrm{Pb}]_{\mathrm{i}}=1\right.$ and $\left.10 \mathrm{mM}\right)$ with crystals of gypsum and/or calcite under atmospheric conditions. This interaction resulted in a reduction of the concentration of lead in the liquid phase due to the precipitation of newly formed Pb-bearing solid phases. The extent of this $\mathrm{Pb}$ removal mainly depended on the nature of the primary mineral phase involved in the interaction. Thus, when gypsum was the only solid phase initially present in the system, the Pb-bearing liquid-gypsum interaction resulted in $\mathrm{Pb}$ removals in the 98-99.8\% range, regardless of $[\mathrm{Pb}]_{\mathrm{i}}$. In contrast, when the interaction took place with calcite, $\mathrm{Pb}$ removal strongly depended on $[\mathrm{Pb}]_{\mathrm{i}}$. It reached $99 \%$ when $[\mathrm{Pb}]_{\mathrm{i}}=1 \mathrm{mM}$, while it was much more modest $(\sim 13 \%)$ when $[\mathrm{Pb}]_{i}=10 \mathrm{mM}$. Interestingly, Pb-removal was maximized for both $[\mathrm{Pb}]_{\mathrm{i}}(99.9 \%$ for solutions with $[\mathrm{Pb}]_{\mathrm{i}}=10 \mathrm{mM}$ and $99.7 \%$ for solutions with $[\mathrm{Pb}]_{\mathrm{i}}=1 \mathrm{mM}$ ) when Pb-polluted solutions simultaneously interacted with gypsum and calcite crystals. Despite the large $\mathrm{Pb}$ removals found in most of the cases studied, the final $\mathrm{Pb}$ concentration $\left([\mathrm{Pb}]_{\mathrm{f}}\right)$ in the liquid phase was always well above the maximum permitted in drinking water $(0.01 \mathrm{ppm})$, with the minimum $\left([\mathrm{Pb}]_{\mathrm{f}}=0.7 \mathrm{ppm}\right)$ being obtained for solutions with $[\mathrm{Pb}]_{\mathrm{i}}=1 \mathrm{mM}$ after their interaction with mixtures of gypsum and calcite crystals. This result suggests that integrating the use of mixtures of gypsum-calcite crystals might help to develop more efficient strategies for in-situ decontaminating $\mathrm{Pb}$-polluted waters through mineral coprecipitation processes.
\end{abstract}

Keywords: lead; removal; calcite; gypsum; coprecipitation

\section{Introduction}

The quantity and the quality of available freshwater have been steadily declining over the last century in both industrialized and developing countries. Human activities like farming, mining, or manufacturing, which provoke the continuous rise of salinity and pollutant contents of freshwater in many sites worldwide overworld, are the main factors of this decline [1-4], as well as the adoption of new lifestyles by large groups of citizens in densely populated cities, which is responsible for the general increase of the drug and pharmaceutic contents in wastewaters. The current scenario of progressive climate warming, which sketches a future of groundwaters with increasing salinity, adds stress on the availability of clean fresh water supplies around the world [5].

$\mathrm{Pb}$ is a most hazardous heavy metal whose concentration in the atmosphere, soils, and waters underwent a striking worldwide increase during the 20th century associated with the development of the automobile industry and the generalized use of leaded gasolines 
until their banning in the 1980s [6,7]. Other industrial activities like the production of ammunition, batteries, pigments, and certain glasses have also contributed anthropogenic $\mathrm{Pb}$ inputs to the hydrosphere and the biosphere [8-12]. Mining activities have contributed to the long-term release of $\mathrm{Pb}$ as a result of the interaction of large volumes of fine-grained $\mathrm{Pb}$-ores exposed in tails with groundwaters and running waters [13-17]. Furthermore, most catastrophic emissions of $\mathrm{Pb}$ environments, which have caused lasting damage in subaquatically and subaerially with great impact on soil fertility and productivity and wildlife diversity, have resulted from punctual wastewaters spills in mine sites and tails [18-20]. $\mathrm{Pb}$ was the main component of plumbing instalments in worldwide households until the 1970s, after which the use of lead pipes rapidly declined in industrialized countries. Interestingly, $\mathrm{Pb}$-related pollution of drinking water has become a hot topic in recent years as information on the relationship between the presence of lead-tainted water pipes in old buildings and high $\mathrm{Pb}$ contents being found in the blood and bones of children in deprived neighborhoods in industrialized countries has reached the news [12,21]. Since $\mathrm{Pb}$ is potentially toxic to mammals, water pollution that results in excessive $\mathrm{Pb}$ intake often has dramatic impacts on human health, including long-lasting damage to the nervous, skeletal, circulatory, enzymatic, endocrine, and immune systems $[17,18,22-26]$. This damage is particularly dramatic in the case of sensitive populations, like children, pregnant women, and elderly people [27-30].

The bioavailability of dissolved $\mathrm{Pb}$ in natural environments is largely controlled by sorption processes that develop during the interaction between $\mathrm{Pb}$-polluted waters and the surface of rock-forming minerals like calcite and gypsum, which are especially abundant in sedimentary basins as main constituents of limestones (calcite) and sulfate evaporitic deposits (gypsum) [31-33]. Sorption of pollutants by mineral surfaces can take place through different mechanisms, including adsorption, absorption, and surface precipitation [34-37]. The first mechanism, adsorption, involves the bonding of the pollutant to the mineral surface by chemical bonds that can be relatively strong, or through longer-range coulomb forces and/or hydrogen bonds. The second mechanism, absorption, requires the diffusion of the pollutant into the structure of the mineral. Adsorption contribution to sorption is significant in the case of minerals like zeolites, whose structures contain large, interconnected channels that allow for ion exchange to occur at relevant rates [38]. In contrast, under the temperature conditions reigning in surface and subsurface environments, the kinetics ion diffusion through carbonate and sulfate mineral structures is most sluggish and absorption contribution to sorption can be considered negligible. The third mechanism, surface precipitation, involves the co-precipitation of the pollutant which incorporates in the crystal structure of new mineral phase. This new phase forms through the chemical reaction between the pollutant and ions that are released to the fluid phase due to the dissolution of the primary mineral. This sorption mechanism commonly progresses by the development of coupled dissolution-crystallization reactions. Coupled dissolution-crystallization reactions are commonplace in surface and subsurface geological environments, where they affect primary mineral phases that can be highly soluble, like halite $(\mathrm{NaCl})$, relatively soluble, like gypsum, or sparingly soluble [39-42], like leucite or wollastonite [43-45]. Further evidence of the widespread nature of these reactions in natural environments have also been provided by a variety of macroscopic and microscopic experiments [46,47]. In fact, coupled dissolution reactions that involve different sulfate and carbonate minerals are considered an effective long-term way of removing inorganic pollutants from natural water and wastewaters [48-51] as well as reducing the increase atmospheric $\mathrm{CO}_{2}[52,53]$. Indeed, in situ AFM imaging has unraveled that coupled dissolution-crystallization reactions that involve calcite effectively remove pollutants like manganese [54], cadmium [37], lead [55], phosphate [56,57], and chromate [58] from aqueous solutions. Similarly, coupled dissolution-crystallization reactions that occur during gypsum-aqueous solution interaction can result in the sequestration of dissolved components like barium and strontium [59], lead [60], arsenate [61], phosphate [62,63], and carbonate [64] through their immobilization in the structure of new phase. 
Different authors have applied microscopic and macroscopic approaches to study the influence of the interaction of $\mathrm{Pb}$-bearing fluids and common calcium-bearing carbonate and sulfate rock-forming minerals (namely, calcite, aragonite, gypsum, and anhydrite) in the fate of dissolved $\mathrm{Pb}$ in natural environments. This interaction has been addressed in numerous studies, most of which have been conducted at room temperature, using very fine-sized crystals (crystal size in the micrometer range), and considering circumneutral to slightly basic $\left(\mathrm{pH}_{\mathrm{i}}=7-8\right) \mathrm{pHs}$ as well as initial $\mathrm{Pb}\left(\left[\mathrm{Pb}_{\mathrm{i}}\right]\right)$ contents $\leq 1000 \mathrm{ppm}[49,65-70]$. Some studies have assessed the long-term immobilization of $\mathrm{Pb}$ by calcium carbonate mineral surfaces conducting ageing experiments [66,69]. Recently, Di Lorenzo et al. [71] conducted an in-depth analysis of the characteristics of $\mathrm{Pb}$ immobilization by calcite and aragonite surfaces.

Although gypsum and calcite often appear spatially and genetically associated in sedimentary basins, in our knowledge, all previous experimental studies of the interaction between Pb-bearing aqueous solutions and gypsum and calcite have been conducted considering these phases separately, forgetting the fact that the dissolution of any of these Ca-bearing minerals can significantly alter physicochemical features of the aqueous solution like alkalinity, $\mathrm{pH}$, or saturation state, thereby influencing the characteristics of the interaction of the fluid phase with the counterpart Ca-bearing mineral. Aiming to fill this gap, in this work we investigate the interaction of $\mathrm{Pb}$-bearing aqueous solutions with gypsum and calcite, first separately and then simultaneously. We assess the degree of $\mathrm{Pb}$ removal from the liquid phase that is achieved depending on the solid phases involved in the interaction. Furthermore, in each case, we evaluate the relationship between the initial $\mathrm{Pb}$ concentration in the solution and the kinetics of the $\mathrm{Pb}$ removal. We focus our study on slightly acidic $\mathrm{Pb}$-bearing aqueous solutions because acidic $\mathrm{pH}$ are commonplace in running waters downstream $\mathrm{Pb}$-bearing ore and mining sites. Our results evidence that more $\mathrm{Pb}$ becomes removed from the liquid phase when this simultaneously interacts with both gypsum and calcite than when the interaction only involves one of these phases. Apart from helping to better understand the fate of dissolved $\mathrm{Pb}$ in geological settings where sedimentary formations are predominant, taking this result into consideration might help to design more efficient strategies for decontaminating Pb-polluted waters through mineral coprecipitation processes.

\section{Experimental Methods}

Interaction experiments between gypsum and/or calcite natural crystals and $\mathrm{Pb}$ bearing aqueous solutions $(50 \mathrm{~mL})$ equilibrated with atmospheric $\mathrm{pCO}_{2}\left(10^{-3.5} \mathrm{~atm}\right.$.) were conducted under ambient temperature conditions $\left(\sim 20-22^{\circ} \mathrm{C}\right)$. The Pb-aqueous solutions (1 and $10 \mathrm{mM}$ ) were prepared by dissolving reagent-grade $\mathrm{Pb}\left(\mathrm{NO}_{3}\right)_{2}$ (Panreac) in high purity deionized water (MiliQ) $(18 \mathrm{M} \Omega \mathrm{cm})$. A set of experiments was carried out with $1 \mathrm{~g}$ of gypsum, calcite, or mixtures of gypsum and calcite (1:1) crystal grains with a relatively high size (average 3-4 mm) to avoid a fast dissolution of the primary minerals. To prepare these crystal grains, large natural optically clear selenite-type gypsum crystals (Alameda de la Sagra, Toledo, Spain) and Iceland spar quality calcite crystals (Proaza, Asturias, Spain) were first crushed in an agate mortar, then sieved to the selected size range, and, finally, cleaned in an ethanol bath. Furthermore, the so-obtained crystal grains were inspected under a stereomicroscope Leica MZ75 (Leica microsystems) and impurity fragments were hand-picked and removed by using $50 \times$ magnification. Pb-bearing solutions and crystals were placed in a glass vessel. The system was then sealed with parafilm to avoid contact with the atmosphere and minimize evaporation. The aqueous solution was gently stirred (stirring rate $<60 \mathrm{rpm}$ ) along the duration of the experiment (from $5 \mathrm{~min}$ up to $96 \mathrm{~h}$ ) by means of a magnetic stirrer. To avoid crystal fragmentation due to stirring-related impacts, a floating magnet was used. Additionally, further experiments carried out with mixtures of gypsum and calcite or with single calcite were made last, up to 7 days or 30 days, respectively, to assess the impact of long interaction times on $\mathrm{Pb}$ removal. Independent 
experimental runs were conducted for each initial physicochemical condition considered. Furthermore, experiments were run triplicate to confirm experimental reliability.

The $\mathrm{pH}$ of the $\mathrm{Pb}$-bearing solutions was measured prior to the beginning of the experiments and immediately after the experiments were terminated using a digital $\mathrm{pH}$ meter ( $\mathrm{pH}$ Meter basic 20-CRISON). Initial $\mathrm{pH}$ values were $4.59 \pm 0.05$ for the solution with $[\mathrm{Pb}]_{\mathrm{i}}=1 \mathrm{mM}$ and $\mathrm{pH}=4.42 \pm 0.05$ for the solution with $[\mathrm{Pb}]_{\mathrm{i}}=10 \mathrm{mM}$. Samples of both the liquid and the solid phases were collected after experiments were terminated. The liquid phase was, then, first filtered through a $0.45 \mu \mathrm{m}$ Millipore membrane and, afterwards, the concentrations of $\mathrm{Pb}$ and $\mathrm{Ca}$ were analyzed using an induced coupled plasma mass spectrometer (ICP-MS 7700 Agilent Technologies). The efficiency of the lead removal was expressed as the percentage of the initial concentration of $\mathrm{Pb}$ that had been eliminated from the solution $\left(\left(\left([\mathrm{Pb}]_{\mathrm{i}}-[\mathrm{Pb}]_{\mathrm{f}}\right) /[\mathrm{Pb}]_{\mathrm{i}}\right) \times 100\right)$. The evolution of physicochemical conditions in the system as the interaction between the lead-bearing aqueous solutions $\left([\mathrm{Pb}]_{\mathrm{i}}=10 \mathrm{mM}\right.$ and $\left.[\mathrm{Pb}]_{\mathrm{i}}=1 \mathrm{mM}\right)$, equilibrated with atmospheric $\mathrm{pCO}_{2}\left(\mathrm{SI}_{\mathrm{CO} 2}=-3.3\right)$, and $200 \mathrm{mg}$ of a calcite-gypsum mixture (50:50) progresses was modeled using the geochemical code PHREEQC [72] and the minteq.dat database. The results of this modeling were used to interpret our observations.

The solid phase sample was immediately washed with ethanol and then dried overnight at room temperature. Afterwards, scanning electron microscope SEM, JEOL6610LV (JEOL, Ltd., Akishima, Japan) imagining was used to identify dissolution features and newly formed phases on the surface of crystal grains. Energy-dispersive X-ray spectroscopy (EDX, INCA Energy 350; Oxford Instruments, Abingdon-on-Thames, UK) semiquantitative analyses on selected areas of the interacted samples provided information on the chemical composition of these newly formed phases. Raman spectra were collected from the surface of interacted crystals. Furthermore, in those experiments where precipitation from the bulk was observed, solutions were filtered after termination time and the recovered solids were also analyzed by Raman spectroscopy. All Raman spectra from 200 to $4000 \mathrm{~cm}^{-1}$ were obtained at room temperature on a microRaman BKTEK using as the excitation source the $532 \mathrm{~nm}$ line of an Ar ion laser and excitation times of $10 \mathrm{~s}$. Powder X-ray diffraction (XRD) was used to identify the newly formed phases on the crystal surfaces and the precipitates from the bulk solution. Previously, interacted solid samples were powdered in an agate mortar. A PAN analytical X'Pert Pro diffractometer was used to collect the diffraction data from 5 to $80^{\circ} 2 \theta$ using $\mathrm{CuK} \alpha$ radiation with a step size of $0.02^{\circ}$. XRD patterns were processed with X'Pert HighScore Plus (PANalytical B.V., Erie, PA, USA) software.

\section{Results}

The processes that take place during the interaction between $\mathrm{Pb}$-bearing aqueous solutions and gypsum, calcite, or mixtures of gypsum and calcite crystals were studied by monitoring both chemical changes in the liquid phase and mineralogical changes in the solid phase in macroscopic batch experiments. Significant differences regarding the kinetics of both the dissolution of the primary phases and the precipitation of newly-formed $\mathrm{Pb}$-bearing secondary phases are observed depending on (i) the initial $\mathrm{Pb}$ concentration $\left([\mathrm{Pb}]_{\mathrm{i}}\right)$ and (ii) the solid phase(s) originally present in the system.

\subsection{Chemical Evolution of the Liquid Phase}

In all the experiments, the solution $\mathrm{pH}$ followed a similar evolution trend, which was characterized by a short initial period of marked $\mathrm{pH}$ increase that transitioned to an almost steady $\mathrm{pH}$. This transition took place at different rates depending on the initial conditions, which determined that different final $\mathrm{pHs}$ were reached in the different experiments (Figure 1). Thus, when the $\mathrm{Pb}$-bearing aqueous solution exclusively interacted with gypsum, the $\mathrm{pH}$ remained approximately constant (under the unavoidable analytical error), with values that were close to 5 along the whole duration of the experiments. 

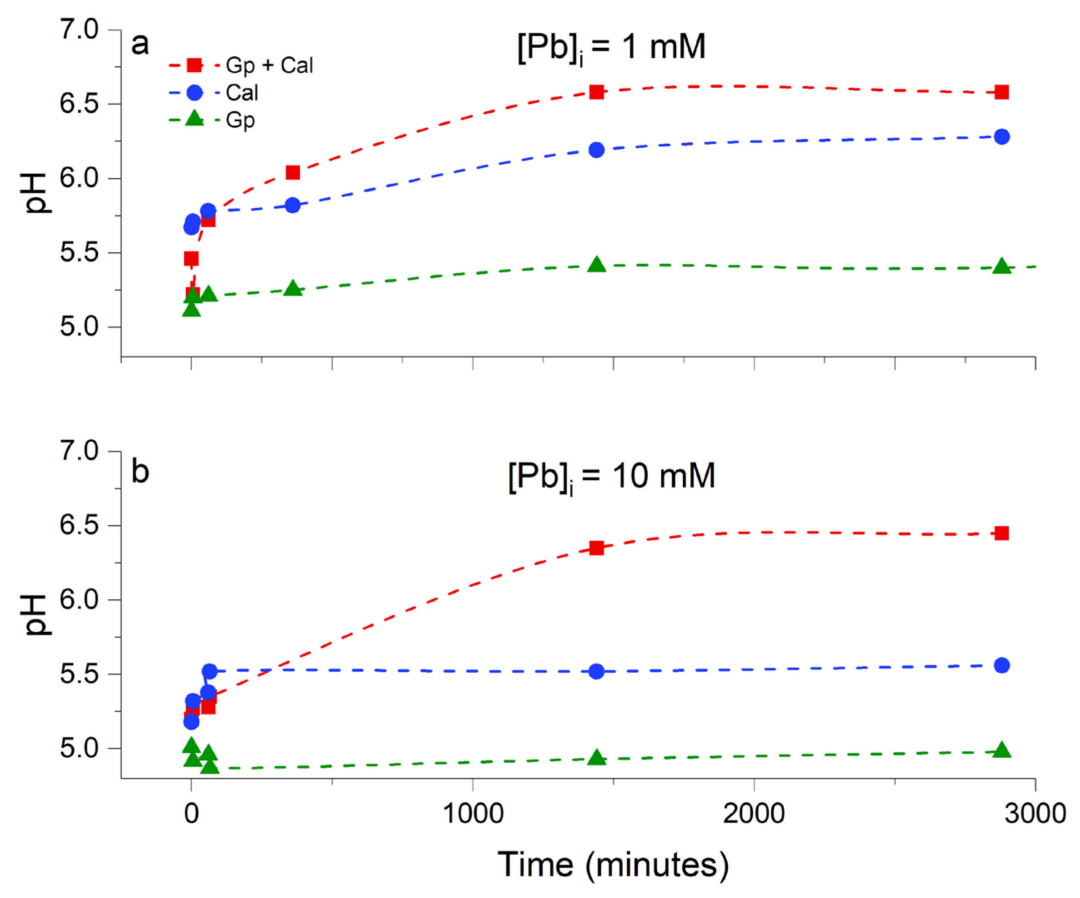

Figure 1. Evolution of the $\mathrm{pH}$ values during interaction of dissolved lead $[\mathrm{Pb}]_{\mathrm{i}}=1 \mathrm{mM}(\mathbf{a})$ and $[\mathrm{Pb}]_{\mathrm{i}}=10 \mathrm{mM}(\mathbf{b})$ with calcite $(\mathrm{Cal})$, gypsum $(\mathrm{Gp})$, and mixtures of both phases $(\mathrm{Gp}+\mathrm{Cal})$. The curves represent a modifier Bezier connection among the average values of three replicate experiments.

When the interaction took place with calcite, the initial $\mathrm{pH}$ increase was marked during the first minutes of the experiment. Afterwards, an asymptotic $\mathrm{pH}$ value $\left(\mathrm{pH}_{\mathrm{f}}=5.6\right)$ was reached almost immediately when the interaction occurred with a solution with $[\mathrm{Pb}]_{\mathrm{i}}=10 \mathrm{mM}$. In contrast, in the experiment where calcite crystals interacted with a solution with $[\mathrm{Pb}]_{\mathrm{i}}=1 \mathrm{mM}$, the $\mathrm{pH}$ continued to slowly grow during the latest stages of the experiments, with the solution showing a $\mathrm{pH}_{\mathrm{f}}=6.3$ at termination time (Figure 1 ).

The highest final $\mathrm{pHs}$ were found when $\mathrm{Pb}$-bearing solutions simultaneously interacted with both gypsum and calcite crystals. In this case, an initial marked $\mathrm{pH}$ increase was also observed. This was followed by a steady slow $\mathrm{pH}$ increase to reach an asymptotic $\mathrm{pH}$ value $\sim 24 \mathrm{~h}$ after the beginning of the experiment, with $\mathrm{pH}_{\mathrm{f}}=6.6$ and 6.5 for solutions with $[\mathrm{Pb}]_{\mathrm{i}}=1$ and $10 \mathrm{mM}$, respectively.

Figures 2a and 3a depict the evolution of Ca concentration ([Ca]) along experiments. In all the cases, there was no $\mathrm{Ca}$ in the aqueous phase when experiments started $\left([\mathrm{Ca}]_{i}=0\right)$. However, as experiments progressed, [Ca] underwent a progressive increase whose characteristics mainly depended on the mineral phase(s) involved in the interaction. Thus, when Pb-bearing aqueous solutions interacted with gypsum, [Ca] increased very rapidly to reach an asymptotic value after only $6 \mathrm{~h}$ interaction (see green line in Figures 2 and 3). This asymptotic $[\mathrm{Ca}]$ value was $\sim 700 \mathrm{ppm}$ in solutions with $[\mathrm{Pb}]_{\mathrm{i}}=1 \mathrm{mM}$ and $1000 \mathrm{ppm}$ in solutions with $[\mathrm{Pb}]_{i}=10 \mathrm{mM}$.

When $\mathrm{Pb}$-bearing aqueous solutions interacted with calcite crystals, [Ca] increased at a very slowly rate along the whole duration of the experiments to reach a value of $\sim 45 \mathrm{ppm}$ at termination time regardless of the $[\mathrm{Pb}]_{\mathrm{i}}$.

The evolution of [Ca] during the interaction with a 50:50 mixture of gypsum and calcite crystals closely resembled that observed during the interaction with only gypsum when $[\mathrm{Pb}]_{\mathrm{i}}=1 \mathrm{mM}$, showing a very rapid initial [Ca] increase to reach a value close to $700 \mathrm{ppm}$ after $6 \mathrm{~h}$ (Figure $3 \mathrm{a}$ ). When $[\mathrm{Pb}]_{\mathrm{i}}=10 \mathrm{mM}$, the interaction of the aqueous solution with gypsum and calcite led to a continuous [Ca] increase. This increase occurred faster during the first $6 \mathrm{~h}$ of the interaction to progressively slow down later on, leading to a [Ca] 
close to 1000 ppm at the experiment's termination time (48 h), without reaching a steady state (Figure 2a).
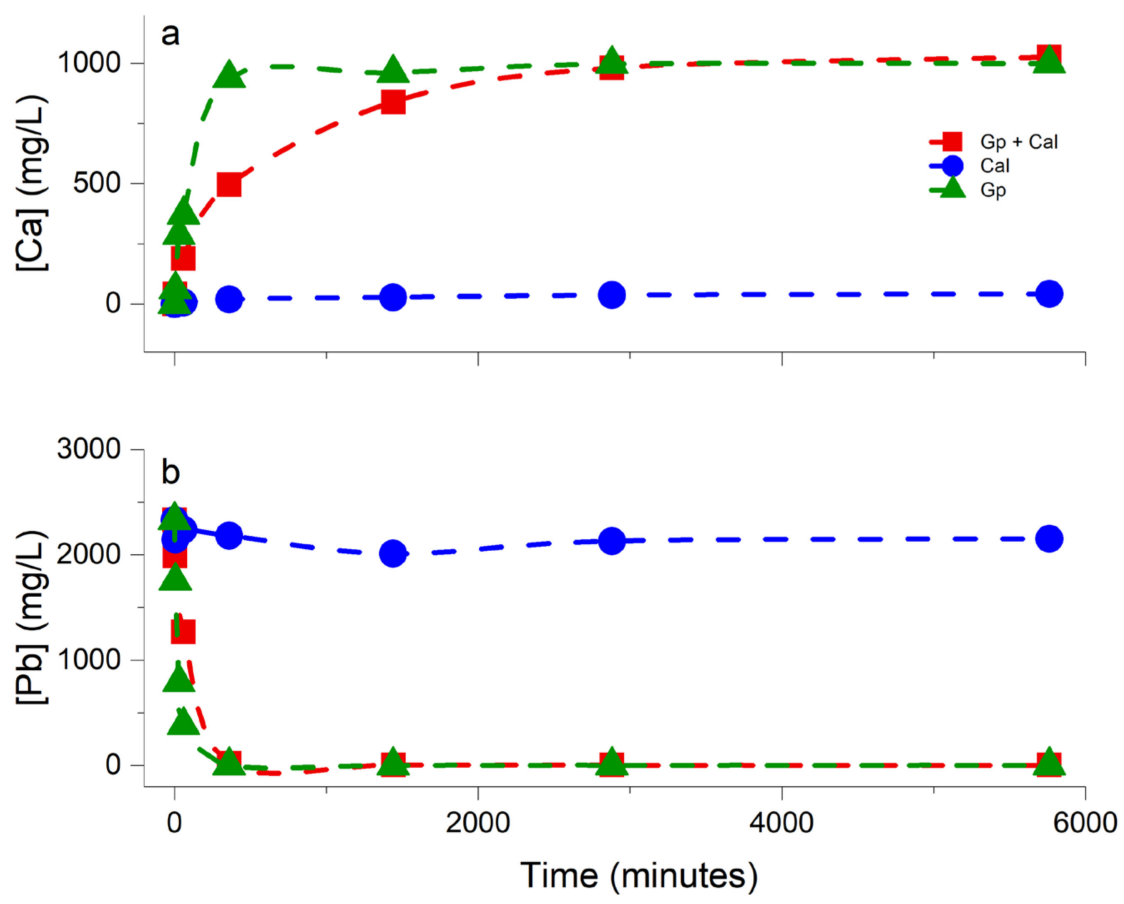

Figure 2. Evolution of $\mathrm{Ca}(\mathbf{a})$ and $\mathrm{Pb}(\mathbf{b})$ concentration as a function of time for interaction experiments carried out with $[\mathrm{Pb}]_{\mathrm{i}}=10 \mathrm{mM}$. The drop in $\mathrm{Pb}$ concentration $(\mathbf{b})$ closely mirrors the release of $\mathrm{Ca}(\mathbf{a})$ to the aqueous solution when the latter interacts with gypsum (Gp). The interaction with calcite (Cal) leads to a very slow [Ca] increase $(\mathbf{a})$ and $[\mathrm{Pb}]$ drop $(\mathbf{b})$ in the aqueous solution. Finally, during the interaction with mixtures of gypsum and calcite $(\mathrm{Gp}+\mathrm{Cal})$ [Ca] continues to increase $(\mathbf{a})$ after [Pb] drops to a steady value $(\mathbf{b})$.

The evolution of $[\mathrm{Pb}]$ as the interaction progressed is depicted in Figures $2 \mathrm{~b}$ and $3 \mathrm{~b}$. As can be seen, in all the experiments, a removal of $\mathrm{Pb}$ was observed, regardless of $[\mathrm{Pb}]_{i}$ and the mineral phase(s) with which the solution interacted. However, the latter factor strongly influenced the extent of this removal. Thus, when the interaction took place with gypsum crystals, $[\mathrm{Pb}]$ rapidly dropped to reach a limit $[\mathrm{Pb}]$ value $\sim 3-4 \mathrm{mg} / \mathrm{L}$ after $48 \mathrm{~h}$ regardless of $[\mathrm{Pb}]_{\mathrm{i}}$. This limit value represented $\mathrm{a} \mathrm{Pb}$ removal of $\sim 98 \%$ for solutions with $[\mathrm{Pb}]_{\mathrm{i}}=1 \mathrm{mM}$ (Figure $3 b$ ) and $\sim 99.8 \%$ for solutions with $[\mathrm{Pb}]_{\mathrm{i}}=10 \mathrm{mM}$ (Figure $2 \mathrm{~b}$ ). In contrast, when the interaction occurred with calcite crystals, both the characteristics of $[\mathrm{Pb}]$ evolution and the final concentration of $\mathrm{Pb}\left([\mathrm{Pb}]_{\mathrm{f}}\right)$ in the solution strongly depended on $[\mathrm{Pb}]_{i}$. Indeed, when the solution contained $[\mathrm{Pb}]_{i}=10 \mathrm{mM}$, its interaction with calcite resulted in a very limited $\mathrm{Pb}$ removal taking place during the experiment time framework. This $\mathrm{Pb}$ removal only reached $2132 \mathrm{ppm}$ after $48 \mathrm{~h}$ of interaction and hardly increased with longer interaction times, reaching $\sim 14 \%$ after $96 \mathrm{~h}$, without showing further increase afterwards. Thus, even after 30 days of interaction the solution still contained $[\mathrm{Pb}]_{30}$ days $=2012 \mathrm{mg} / \mathrm{L}$ (Figure $2 \mathrm{~b}$ ). When the aqueous solution contained a lower $\mathrm{Pb}$ concentration, $[\mathrm{Pb}]_{\mathrm{i}}=1 \mathrm{mM}$, after $48 \mathrm{~h}$ of interaction with calcite crystal $[\mathrm{Pb}]_{48 \mathrm{~h}}=34.2 \mathrm{mg} / \mathrm{L}$, this meant that $84 \%$ of the Pb initially present in the solution had been removed. Further interaction resulted in further $\mathrm{Pb}$ removal, approaching $99 \%$ after $96 \mathrm{~h}\left([\mathrm{~Pb}]_{96 \mathrm{~h}}=2.4 \mathrm{mg} / \mathrm{L}\right)($ Figure $3 \mathrm{~b})$, without reaching a limit $[\mathrm{Pb}]$. 

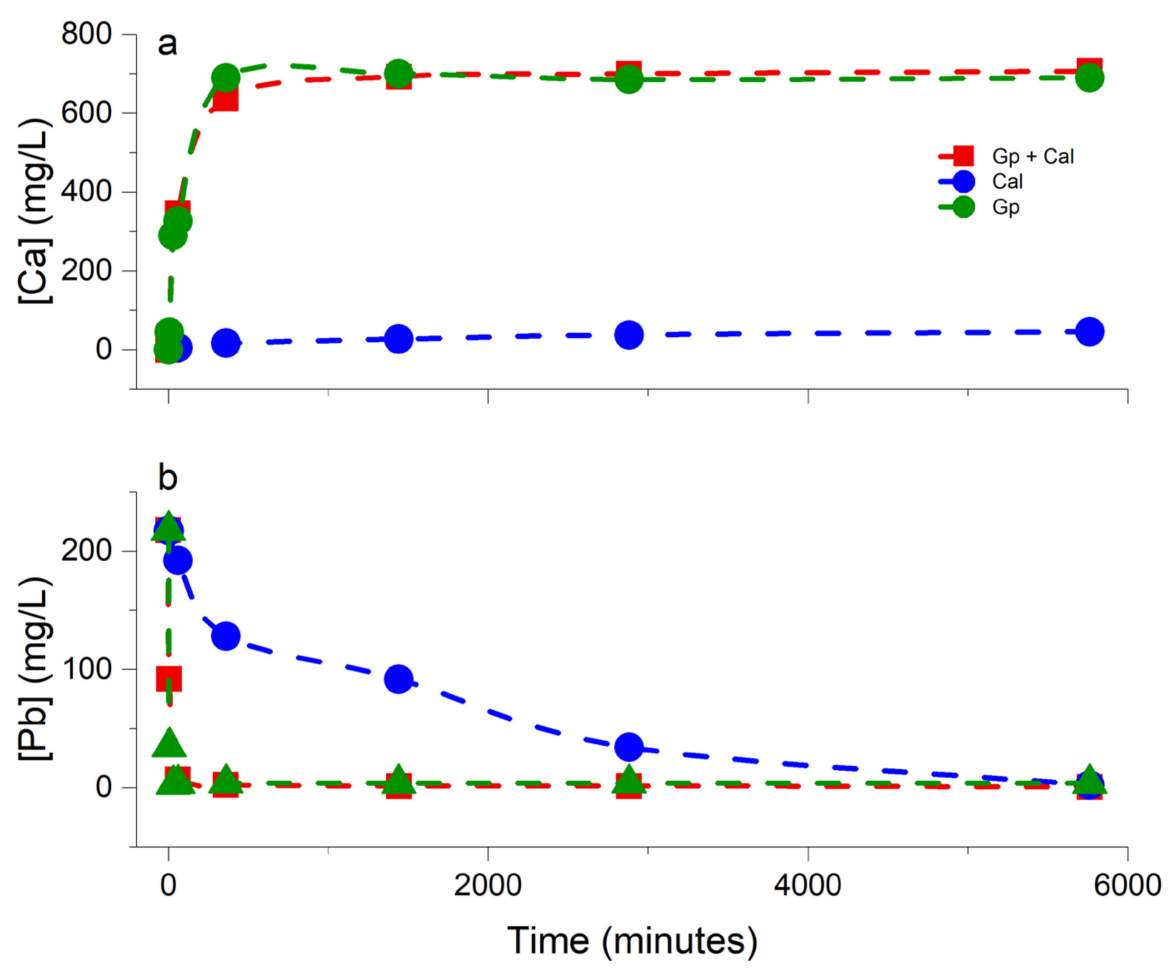

Figure 3. Evolution of $\mathrm{Ca}(\mathbf{a})$ and $\mathrm{Pb}(\mathbf{b})$ concentration as a function of time for interaction experiments carried out with $[\mathrm{Pb}]_{i}=1 \mathrm{mM}$. During the interaction with either gypsum $(\mathrm{Gp})$ or mixtures of gypsum and calcite (Gp + Cal) the release of $\mathrm{Ca}(\mathbf{a})$ was closely mirrored by the removal of $\mathrm{Pb}(\mathbf{b})$ from the Pb-bearing solution. In contrast, during the interaction with calcite (Cal) [Ca] steadily increased at a very slow rate over the whole duration of the experiments (a), while [Pb] underwent a rapid drop during the first $48 \mathrm{~h}$ to continue slowly decreasing afterwards (b).

When the interaction of Pb-bearing aqueous solutions took place with mixtures of gypsum and calcite crystals, the characteristics of $[\mathrm{Pb}]$ evolution mirrored those observed during the interaction with only gypsum for both solutions with $[\mathrm{Pb}]_{\mathrm{i}}=10$ and $1 \mathrm{mM}$ (Figures $2 \mathrm{~b}$ and $3 \mathrm{~b}$ ). [ $\mathrm{Pb}]$ underwent a very rapid drop during the first $24 \mathrm{~h}$ which resulted in a $\mathrm{Pb}$ removal of $99.3 \%$ from the solution with $[\mathrm{Pb}]_{i}=1 \mathrm{mM}$ and $99.8 \%$ from that with $[\mathrm{Pb}]_{\mathrm{i}}=10 \mathrm{mM}$. Further interaction led to a very slow increase in Pb removal. After $96 \mathrm{~h}$, the solution with $[\mathrm{Pb}]_{\mathrm{i}}=1 \mathrm{mM}$ contained $[\mathrm{Pb}]_{96 \mathrm{~h}}=0.7 \mathrm{mg} / \mathrm{L}$, and this meant $\sim 99.7 \%$ of its initial $\mathrm{Pb}$ content had been removed as result of the solution interaction with mixtures of gypsum and calcite. In the case of the solution with $[\mathrm{Pb}]_{\mathrm{i}}=10 \mathrm{mM}$, a similar percentage of $\mathrm{Pb}$ removal $(\sim 99.9 \%)$ was reached after 7 days in contact with calcite crystals. Still, at this stage, the $\mathrm{Pb}$ content of the solution was relatively high $\left([\mathrm{Pb}]_{7 \mathrm{~d}}=1.9 \mathrm{mg} / \mathrm{L}\right)$.

\subsection{Newly Formed Phases: Nature and Morphology}

In all the interaction experiments, the formation of secondary phases was observed, regardless of $[\mathrm{Pb}]_{i}$ and the solid phase(s) initially present in the system. When Pb-bearing aqueous solutions interacted with gypsum, a precipitate was observed to form in the bulk solution. Furthermore, SEM imaging of the surface of interacted gypsum crystals also evidenced the formation of a precipitate (Figure $4 a, b$ ). Both precipitates were confirmed as anglesite $\left(\mathrm{PbSO}_{4}\right)$ by XRD and Raman analysis, respectively (Figures 5 and 6). The morphology of anglesite crystals formed on gypsum surfaces during the early stages of the interaction appeared elongated along the b-axis and showed a habit defined by flat surfaces that belonged to the pinacoid $\{001\}$ and the rhombic prism $\{210\}$, as well as strongly stepped surfaces roughly parallel to (100) (Figure 4a). The latter surfaces appeared serrated and consisted of steps belonging to $\{210\}$. As the interaction progressed, anglesite crystals 
become lozenge-like, with their habit dominated by the pinacoid $\{001\}$ and further bounded by much smaller $\{210\}$ surfaces (Figure $4 b$ ).
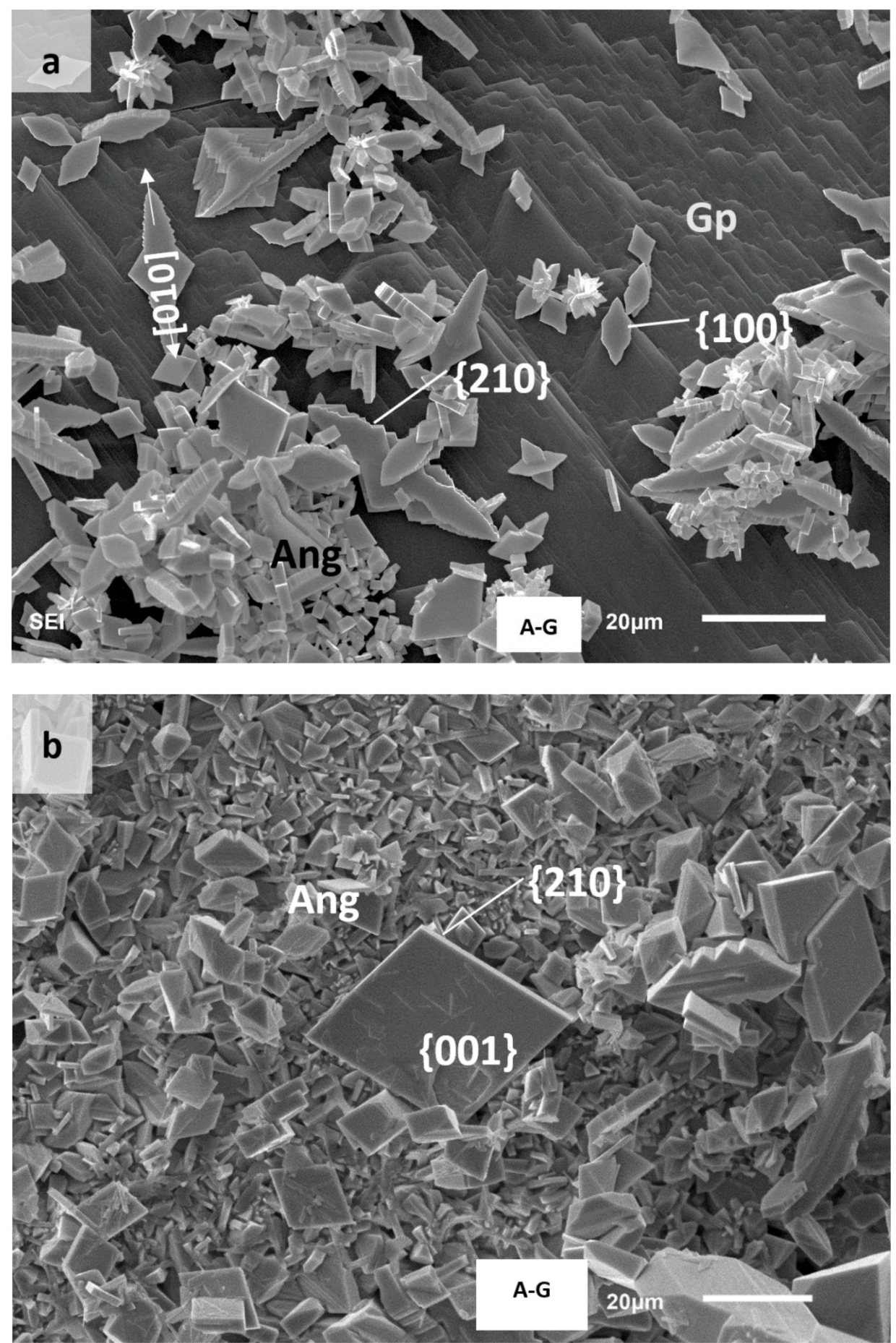

Figure 4. SEM micrographs of anglesite (Ang) formed on gypsum crystals (Gp) interacting with aqueous solutions with $[\mathrm{Pb}]_{\mathrm{i}}=10 \mathrm{mM}$. (a) After 5 min interaction, the development of dissolution features as well as the growth of anglesite crystals are observed on gypsum surfaces. Anglesite crystals initially growth elongated along the b-axis with a habit defined by flat surfaces that belong to the pinacoid $\{001\}$, the rhombic prism $\{210\}$, and stepped surfaces roughly parallel to (100). (b) After $24 \mathrm{~h}$, gypsum surfaces become fully carpeted by anglesite crystals that show a habit dominated by platy faces belonging to the pinacoid $\{001\}$ and smaller $\{210\}$ forms. 


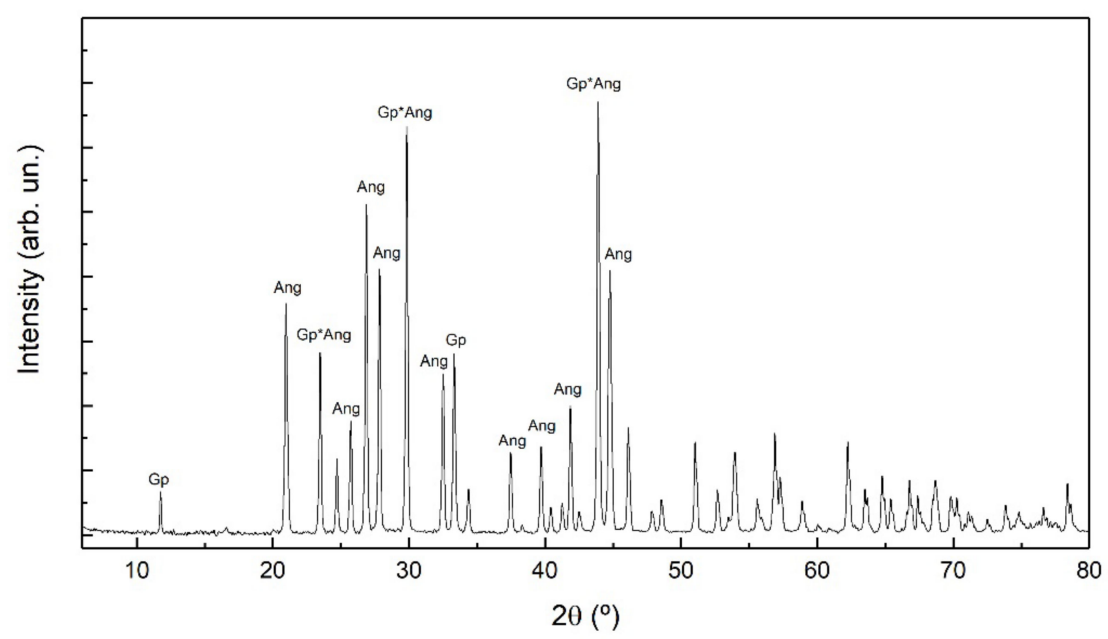

Figure 5. X-ray powder diffraction pattern of gypsum crystal interacting with a Pb-bearing solutions. All diffraction peaks can be assigned to gypsum (Gp) and anglesite (Ang). The sign "*" indicates that one reflection can be asigned to both gypsum (Gp) or Anglesite (Ang).

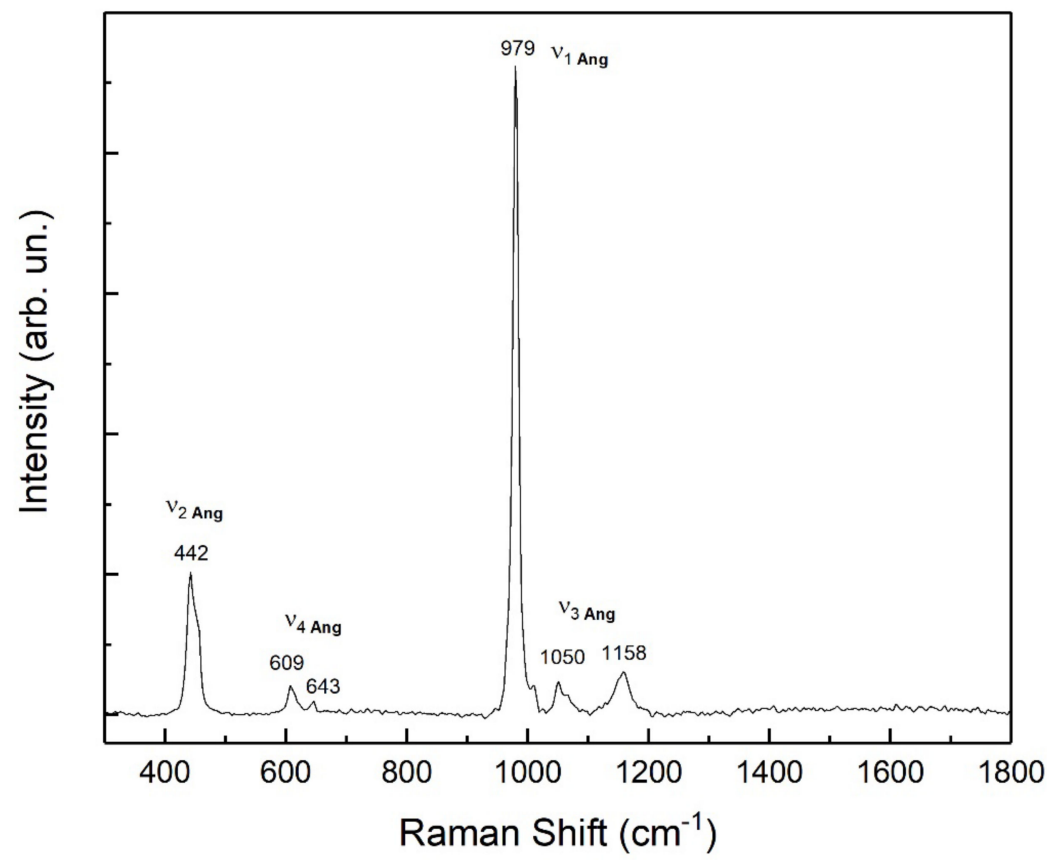

Figure 6. Raman spectra of the precipitate formed in the bulk of a Pb-bearing solution $\left([\mathrm{Pb}]_{\mathrm{i}}=10 \mathrm{mM}\right)$ during its interaction with gypsum crystals. All bands can be assigned to the vibration modes of anglesite.

Different reaction pathways were observed during the interaction between $\mathrm{Pb}$-bearing aqueous solutions and calcite crystals depending on $[\mathrm{Pb}]_{\mathrm{i}}$. When $[\mathrm{Pb}]_{\mathrm{i}}=1 \mathrm{mM}$, SEM imaging calcite surfaces showed the formation of a precipitate that consisted of elongated prismatic crystals (Figure 7a). All peaks in the XRD pattern of these crystals matched well those of cerussite (PDF 5-417) (Figure 8a). A more complex precipitation behavior was observed when a solution with $[\mathrm{Pb}]_{\mathrm{i}}=10 \mathrm{mM}$ interacted with calcite. In this case, the precipitate that formed on the calcite surface consisted of two differently shaped types of crystals: Elongated prisms and hexagonal thin plates (Figure $7 \mathrm{~b}$ ). The X-ray diffraction pattern of this precipitate showed the main features characteristic of cerussite together to a small diffraction peak at $34.075(2 \theta)$ whose location matched well that of the most important 
reflection (110) of hydrocerussite (PDF 13-131) (Figure 8b). Raman spectra of elongated prism-like crystals obtained in surface areas where they were the only newly formed phases showed the typical characteristics of cerussite (Figure 9). Taking into consideration the result of the X-ray diffraction analysis together with morphological criteria, the thin plate-like crystals were attributed to hydrocerussite.
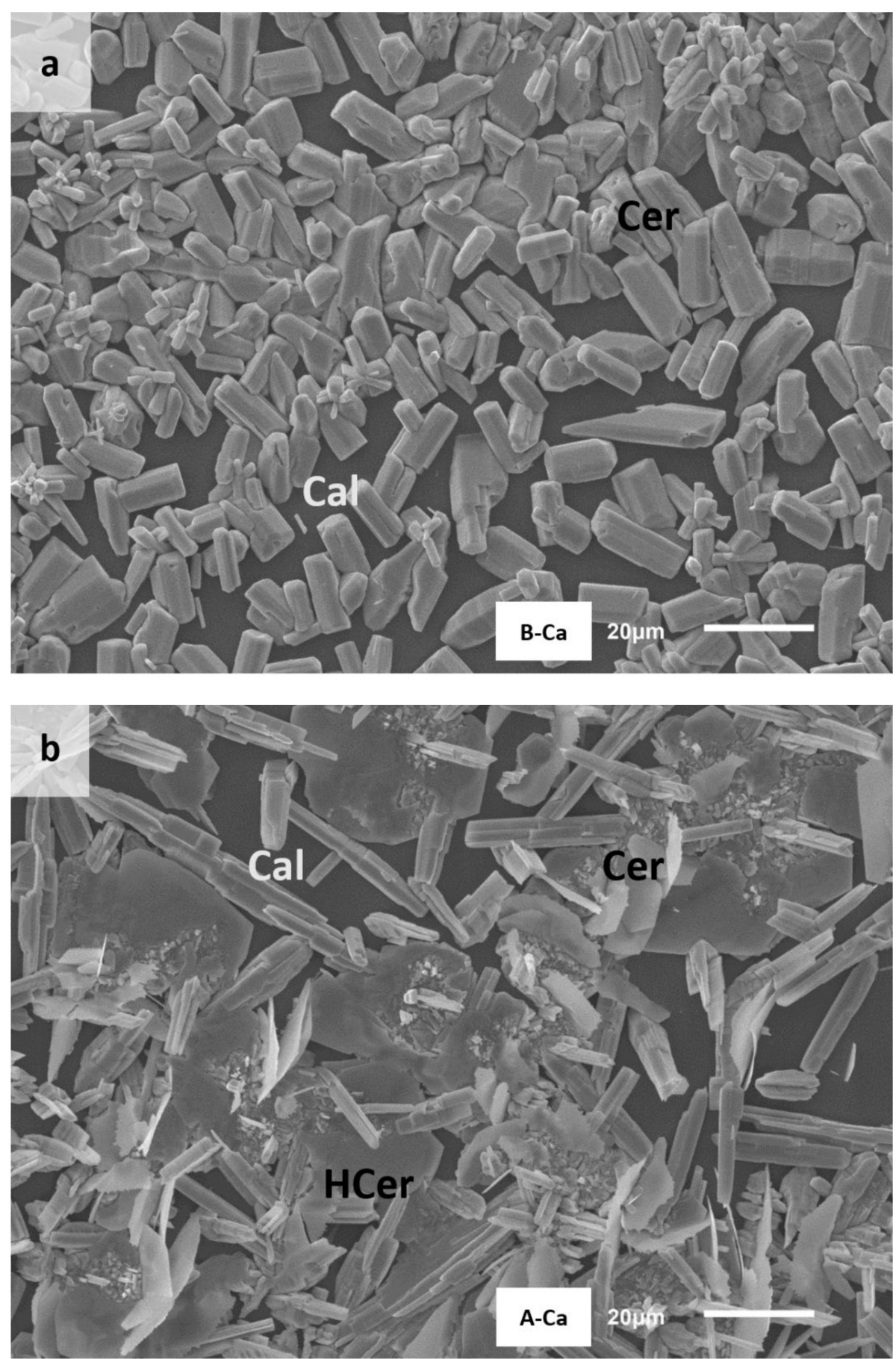

Figure 7. SEM micrographs of new phases formed after $24 \mathrm{~h}$ of interaction between Pb-bearing solutions and calcite crystals (Cal). (a) Cerussite (Cer) appears as prismatic crystals on calcite surface when calcite interacts with a solution with $[\mathrm{Pb}]_{\mathrm{i}}=1 \mathrm{mM}$. (b) When the aqueous solution contains a higher Pb-bearing solution $\left([\mathrm{Pb}]_{\mathrm{i}}=10 \mathrm{mM}\right)$, both prismatic cerussite (Cer) and hexagonal plates of hydrocerussite (HCer) form on calcite surface. 

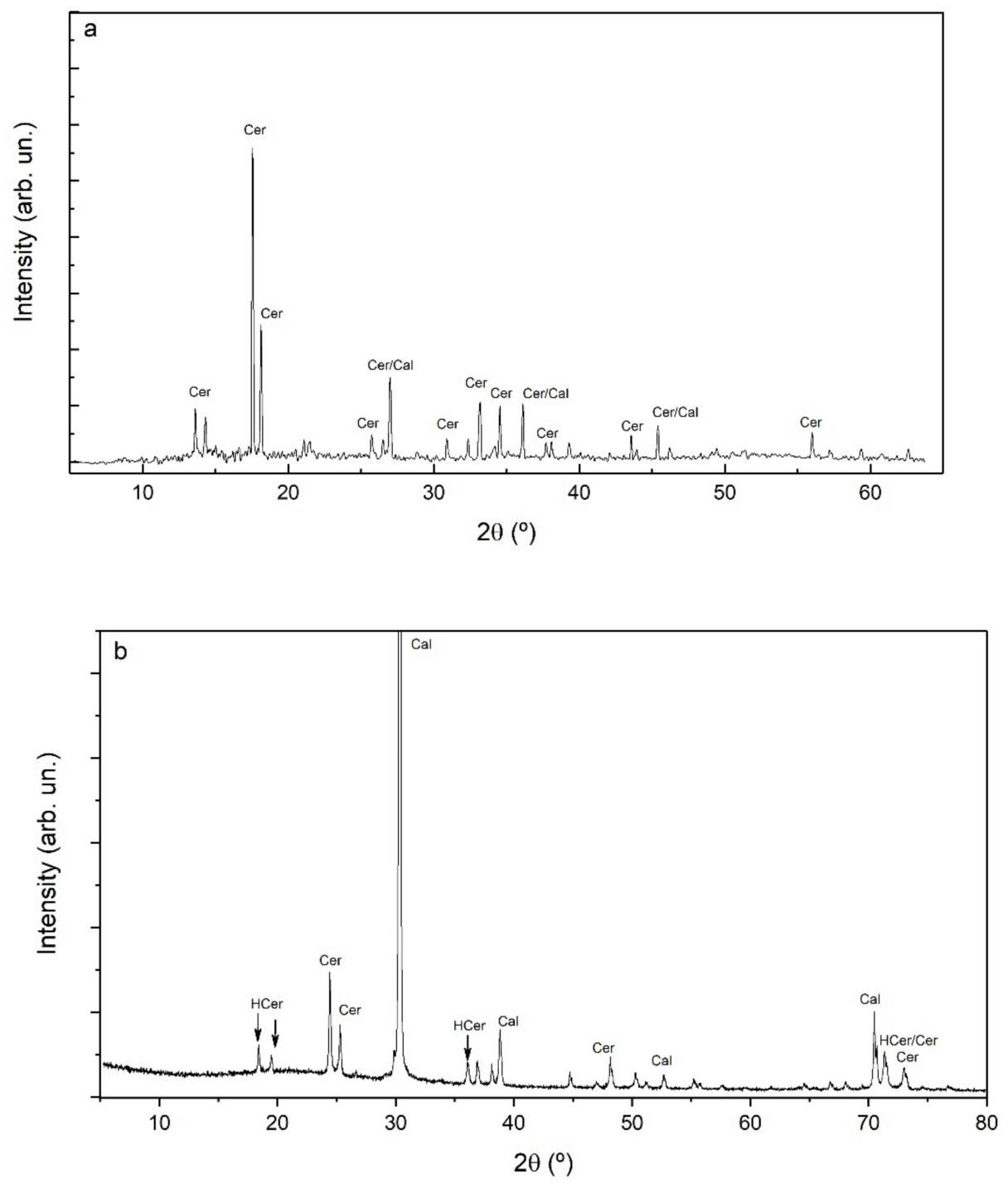

Figure 8. X-ray powder diffraction pattern of precipitates formed on calcite interacting with Pb-bearing solutions. (a) The main reflections of cerussite (Cer) are identified when the reaction takes places with a solution with $[\mathrm{Pb}]_{\mathrm{i}}=1 \mathrm{mM}$. (b) Reflections that match well with hydrocerussite (HCer) and cerussite (Cer) are identified in precipitates formed during the interaction between calcite with solutions with $[\mathrm{Pb}]_{\mathrm{i}}=10 \mathrm{mM}$. 


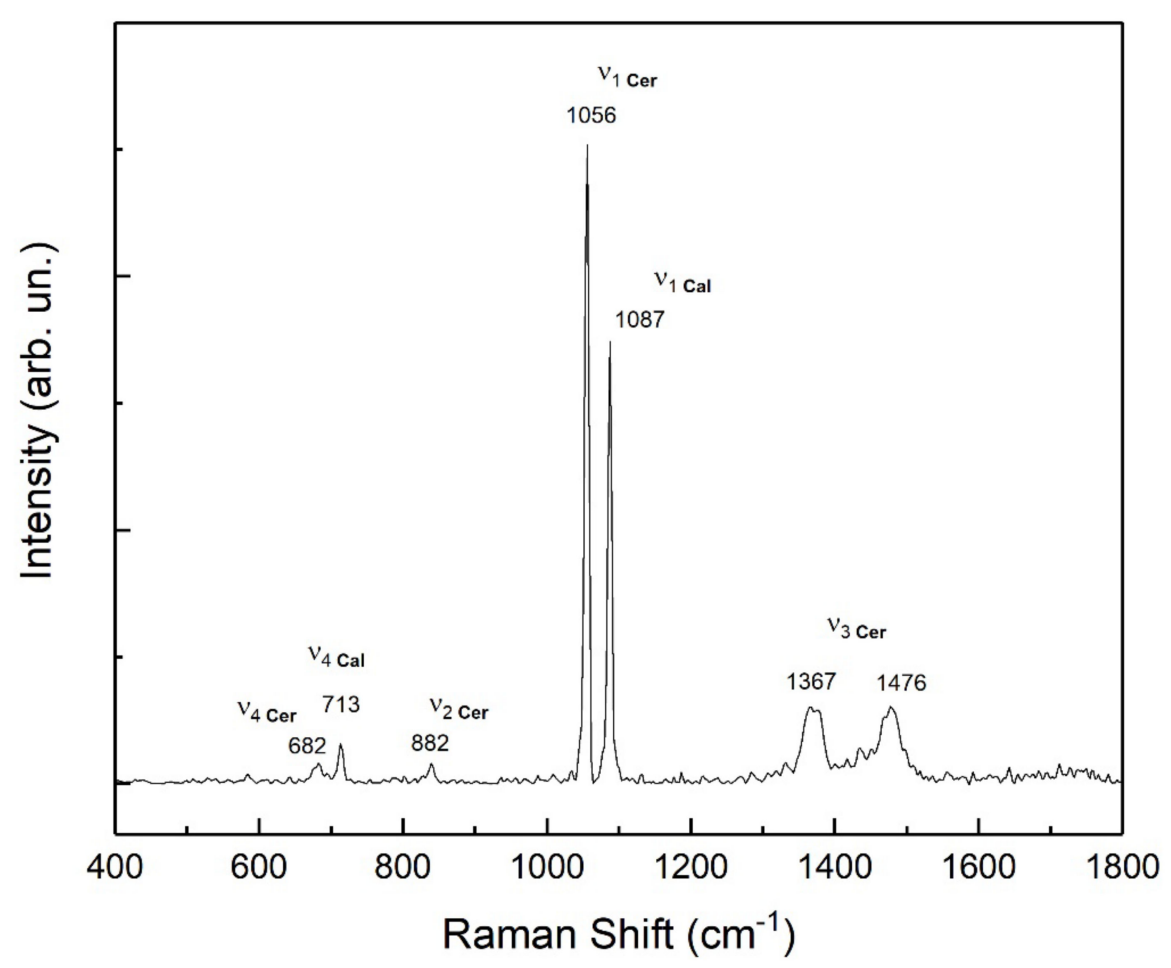

Figure 9. Raman spectra of the precipitate formed on a calcite crystal interacting with $\mathrm{Pb}$-bearing solutions $\left([\mathrm{Pb}]_{\mathrm{i}}=1 \mathrm{mM}\right)$. All bands can be assigned to vibration modes to either cerussite (Cer) or calcite (Cal).

Finally, an influence of $[\mathrm{Pb}]_{i}$ in the nature of newly formed phases was also found during the interaction of $\mathrm{Pb}$-bearing aqueous solutions with gypsum-calcite mixtures. This influence only regarded secondary phases that grew on the calcite surface, since anglesite was the only phase precipitated on gypsum surfaces regardless of $[\mathrm{Pb}]_{\mathrm{i}}$ (Figure 10a). Thus, when $[\mathrm{Pb}]_{\mathrm{i}}=1 \mathrm{mM}$ (Figure 10b), hydrocerussite formed on calcite surfaces. In contrast, the precipitate that formed when calcite interacted with a solution containing $[\mathrm{Pb}]_{\mathrm{i}}=10 \mathrm{mM}$ consisted of anglesite, hydrocerussite, and cerussite (Figure 10c). Furthermore, in the latter case, the relative abundance of these three phases changed as the reaction progressed: The precipitate mainly consisted of hydrocerussite, with a minor content of anglesite and a very minor content of cerussite during the first $5 \mathrm{~min}$ of the interaction. Afterwards, anglesite and hydrocerussite contents progressively decreased, and cerussite became the main component of the precipitate after $24 \mathrm{~h}$. A detailed inspection of the distribution of the precipitate on calcite surfaces evidenced a close spatial relationship between cerussite and hydrocerussite crystals, with most crystals of the former phase growing on the surface of hydrocerussite plates (Figure 10c). No morphological differences were observed between anglesite, cerussite, or hydrocerussite precipitated during the interaction of Pb-bearing solutions with gypsum-calcite mixtures or with gypsum or calcite crystals independently. It is worth noting that only anglesite crystals were observed to precipitate from the bulk solution when gypsum-calcite mixtures were used, regardless of $[\mathrm{Pb}]_{\mathrm{i}}$. 

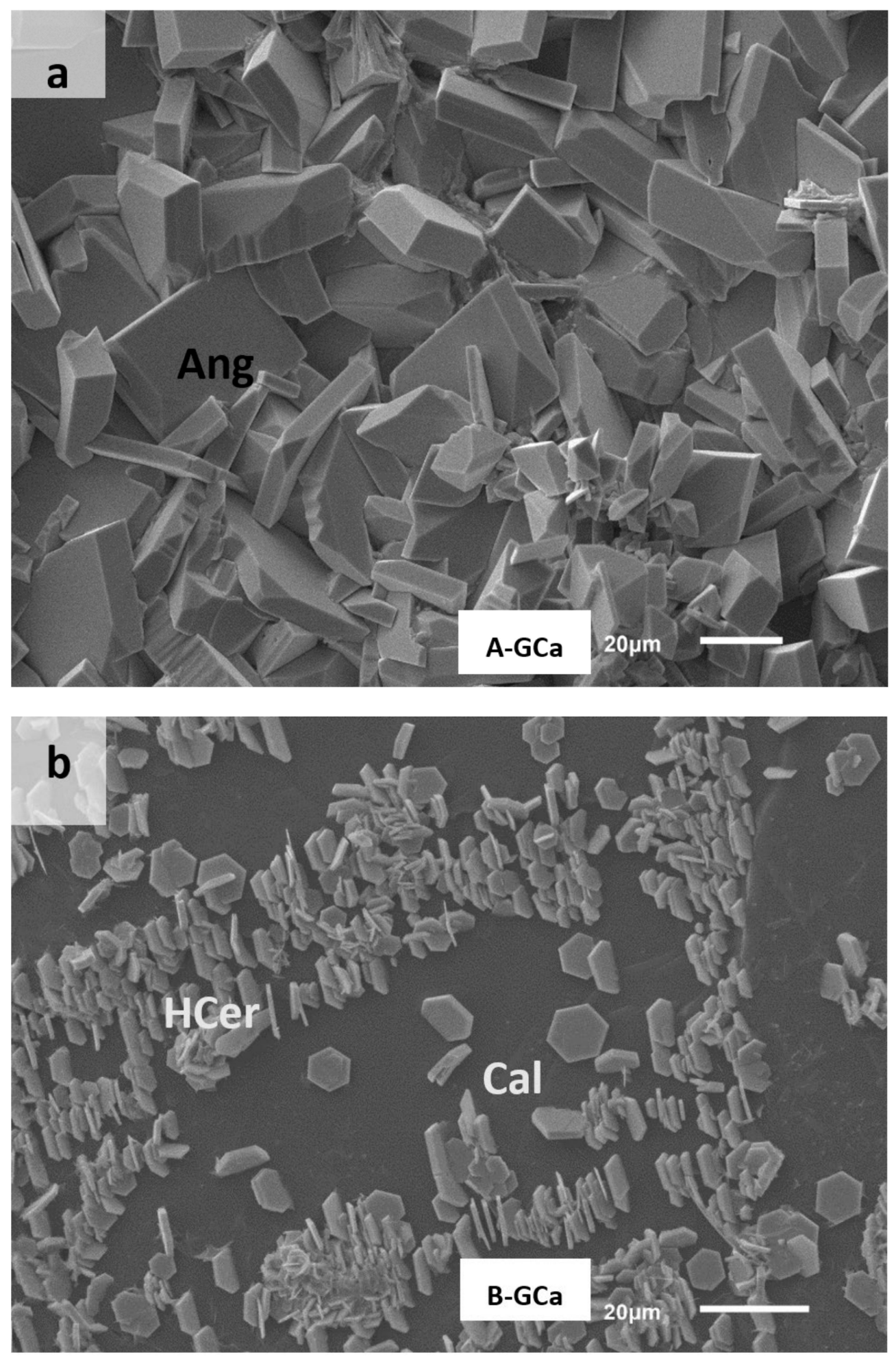

Figure 10. Cont. 


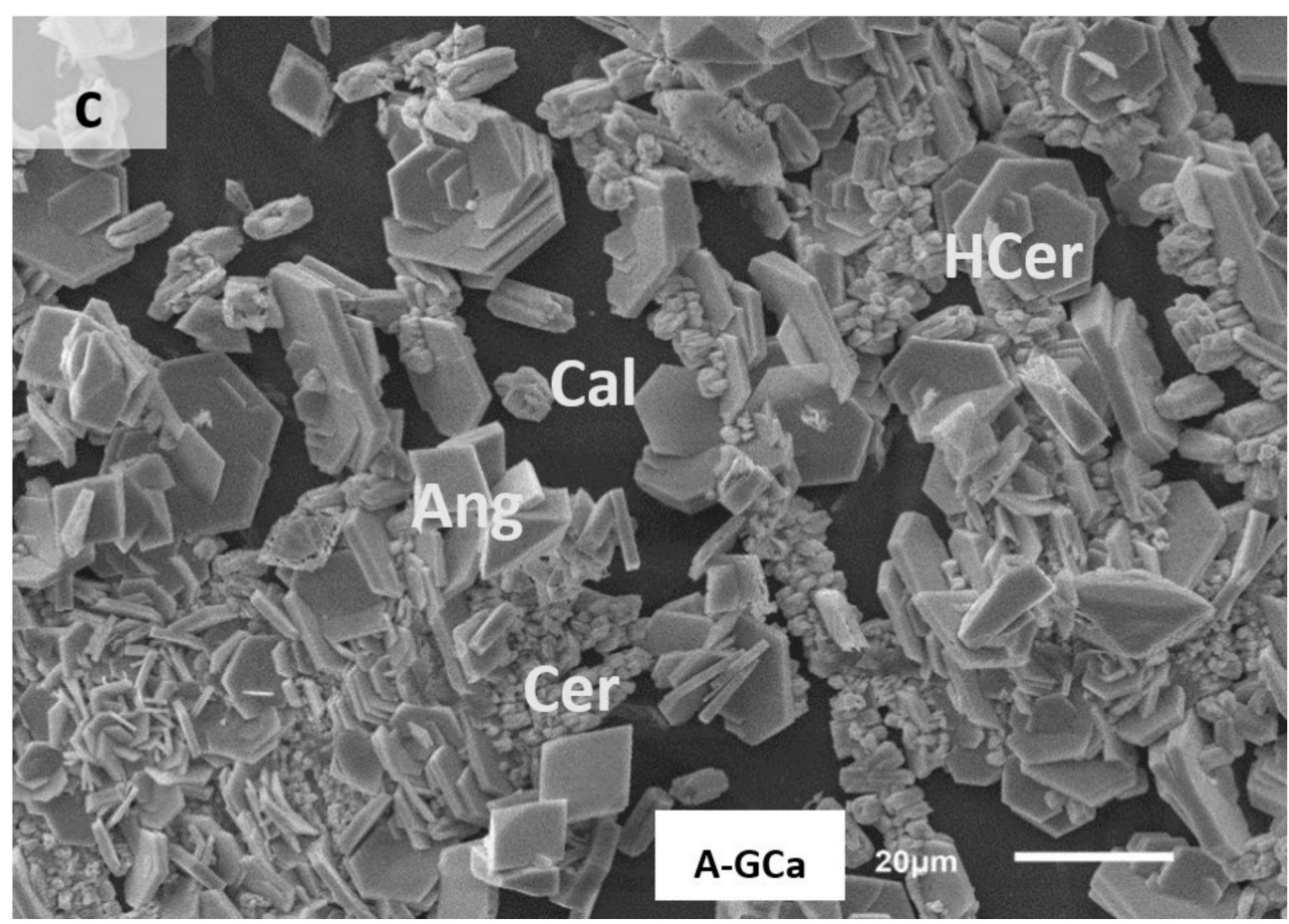

Figure 10. SEM micrographs of phases newly formed after $24 \mathrm{~h}$ of interaction between Pb-bearing solutions and mixtures of gypsum and calcite. (a) A continuous layer of anglesite crystals (Ang) carpet gypsum surfaces interacting with solutions with $[\mathrm{Pb}]_{\mathrm{i}}=10 \mathrm{mM}$. (b) The surface of calcite crystals (Cal) interacting with solutions with $[\mathrm{Pb}]_{\mathrm{i}}=1 \mathrm{mM}$ appears covered by discontinuous patches consisting of hydrocerussite (HCer). (c) The surface of calcite crystal interacting with solutions with $[\mathrm{Pb}]_{\mathrm{i}}=10 \mathrm{mM}$ appears covered by a discontinuous layer of closely intergrown hydrocerussite (HCer) plates and cerussite (Cer) prismatic crystals. A small number of anglesite (Ang) crystals can also be observed scattered on the surface.

\section{Discussion}

\subsection{Effectiveness of Gypsum as Pb Scavenger}

As explained above, the interaction of aqueous solutions bearing $\mathrm{Pb}\left([\mathrm{Pb}]_{\mathrm{i}} \leq 2300 \mathrm{mg} / \mathrm{L}\right)$ with gypsum crystals resulted in a fast and significant removal of $\mathrm{Pb}$ from the fluid, with $[\mathrm{Pb}]_{48 \mathrm{~h}} \sim 3 \mathrm{mg} / \mathrm{L}$ regardless of the value of $[\mathrm{Pb}]_{\mathrm{i}}$. Astilleros et al. and Morales et al. $[49,68]$ reported similar $[\mathrm{Pb}]$ drops in solutions that initially contained $1000 \mathrm{mg} / \mathrm{L} \mathrm{Pb}$ after they interacted gypsum or anhydrite, respectively. According to these authors, [Pb] dropped due to the development of a dissolution-crystallization process. Dissolution-crystallization reactions have been invoked by different authors as the main mechanism responsible for the removal of different dissolved components from aqueous solutions interacting with gypsum crystals $[61,68]$.

This process started as soon as a Pb-bearing aqueous solution that was undersaturated with respect to either gypsum or anhydrite entered in contact with crystals of any of these phases. The dissolution of a calcium sulfate mineral, either gypsum, anhydrite, or the hemihydrated bassanite, released $\mathrm{Ca}^{2+}$ and $\mathrm{SO}_{4}{ }^{-2}$ ions to the $\mathrm{Pb}$-bearing liquid phase, whose supersaturation with respect to anglesite $\left(\mathrm{PbSO}_{4}\right)$ progressively increased. Eventually, the supersaturation threshold that allowed for the formation of anglesite nuclei was overcome and anglesite precipitated after reaction times shorter than 5 min regardless of the $[\mathrm{Pb}]_{\mathrm{i}}$ concentration [68]. The precipitation of anglesite removed both $\mathrm{SO}_{4}{ }^{-2}$ and $\mathrm{Pb}^{2+}$ ions from the aqueous solution and promoted further dissolution of the calcium sulfate phase. Further release of $\mathrm{Ca}^{2+}$ and $\mathrm{SO}_{4}{ }^{-2}$ ions to the fluid promoted further anglesite precipitation, defining of a dissolution-precipitation loop that was operative to remove $\mathrm{Pb}$ from the aqueous phase as long as the balance between calcium sulfate crystal dissolution and anglesite precipitation kept the system undersaturated with respect to the former phase and supersaturated with respect to the latter. The progress of the dissolution-precipitation reactions 
did not induce significant changes in the aqueous solutions $\mathrm{pH}$. The final $[\mathrm{Pb}]_{\mathrm{f}}=3 \mathrm{mg} / \mathrm{L}$ detected in the experiments by Astilleros et al. and Morales et al. $[49,68]$ as well as in this work derived from the solution being simultaneously equilibrated with anglesite and the initially present calcium sulfate phase. This value was directly related to anglesite solubility and, consequently, it represented the minimum $[\mathrm{Pb}]$ that could be achieved when anglesite precipitation was the main mechanism scavenging $\mathrm{Pb}$ from a Pb-bearing solution. This minimum $[\mathrm{Pb}]$ value $(3 \mathrm{mg} / \mathrm{L})$ was still 300 times too high to meet standard potability requirements for drinking water $(10 \mu \mathrm{g} / \mathrm{L})$, according to the World Health Organization and the European Community directive [73]. Therefore, although effective to rapidly remove large $\mathrm{Pb}$ amounts from aqueous solutions, the dissolution-crystallization reaction that operated during the interaction of $\mathrm{Pb}$-bearing solutions with gypsum (and other calcium sulfate rock-forming minerals) could only be considered as an initial step in a strategy for the decontamination of highly polluted waters, which would need to be implemented together with complementary Pb-uptake mechanisms if aimed at the production of drinking water, or even for treating mildly $\mathrm{Pb}$-contaminated waters.

\subsection{Effectiveness of Calcite as $\mathrm{Pb}$ Scavenger}

$\mathrm{Pb}$ removal during the interaction of $\mathrm{Pb}$-bearing aqueous solutions with calcite crystals occurred at a very slow rate compared to that observed when the interaction took place with gypsum. Thus, while in the latter case $[\mathrm{Pb}]_{48 \mathrm{~h}}$ approached $3 \mathrm{mg} / \mathrm{L}$, a slower $\mathrm{Pb}$ removal rate during the interaction with calcite resulted in $[\mathrm{Pb}]_{48 \mathrm{~h}}$ values that were well above 2000 and $100 \mathrm{mg} / \mathrm{L}$ for solutions with $[\mathrm{Pb}]_{\mathrm{i}}=10$ and $[\mathrm{Pb}]_{\mathrm{i}}=1 \mathrm{mM}$, respectively. Moreover, after $96 \mathrm{~h}$ of interaction with calcite, $[\mathrm{Pb}]$ still remained above $2000 \mathrm{mg} / \mathrm{L}$ in solutions with $[\mathrm{Pb}]_{\mathrm{i}}=10 \mathrm{mM}\left([\mathrm{Pb}]_{96 \mathrm{~h}}=2155 \mathrm{mg} / \mathrm{L}\right)$, although it dropped to values below $3 \mathrm{mg} / \mathrm{L}$ in solutions with $[\mathrm{Pb}]_{\mathrm{i}}=1 \mathrm{mM}\left([\mathrm{Pb}]_{96 \mathrm{~h}}=2.4 \mathrm{mg} / \mathrm{L}\right)$. The presence of cerussite and hydrocerussite crystals carpeting the surface of calcite crystals (Figure 7a,b) supported a dissolution-precipitation process as the main mechanism responsible for $\mathrm{Pb}$ removal during this interaction. As explained in the Section 1, dissolution-precipitation was the main operating mechanism that led to effective removal of a variety of dissolved pollutants from aqueous solutions interacting with calcite $[37,55,58]$. The dissolution-precipitation process that operated during the interaction of $\mathrm{Pb}$-bearing solutions and calcite had similar characteristics to those of the gypsum dissolution-anglesite precipitation one described in Section 4.1. In contact with Pb-bearing aqueous solutions, calcite crystals underwent dissolution that resulted in the release of $\mathrm{Ca}^{2+}$ and $\mathrm{CO}_{3}{ }^{-2}$ ions to the liquid. As the concentration of the released $\mathrm{CO}_{3}{ }^{-2}$ ions mounted, the $\mathrm{pH}$ of the solution increased. Both factors determined that the threshold supersaturation for the nucleation of lead carbonate phases was rapidly overcome in the solution. At this point, a calcite dissolution-lead carbonate(s) precipitation feedback loop was established. This loop-operated $\mathrm{pH}$ evolved differently in solutions with different $[\mathrm{Pb}]_{\mathrm{i}}$, reflecting differences in the balance between the amount of $\mathrm{CO}_{3}{ }^{-2}$ ions that were released to the liquid phase through calcite dissolution and the amount of both $\mathrm{CO}_{3}{ }^{-2}$ and $\mathrm{Pb}^{2+}$ ions that became removed from it by precipitation of lead carbonates. In the case of calcite interaction with a solution with $[\mathrm{Pb}]_{\mathrm{i}}=10 \mathrm{mM}$, higher supersaturation with respect to lead carbonates was reached, which resulted in a larger amount of lead carbonate precipitation and, consequently, larger depletion of $\mathrm{CO}_{3}{ }^{2-}$ from the solution than would occur during the interaction of calcite with a solution with $[\mathrm{Pb}]_{\mathrm{i}}=1 \mathrm{mM}$. This larger $\mathrm{CO}_{3}{ }^{2-}$ depletion from solutions with $[\mathrm{Pb}]_{\mathrm{i}}=10 \mathrm{mM}$ could explain that after an initial increase, $\mathrm{pH}$ rapidly reached a steady state value around 5.5 . In contrast, the smaller $\mathrm{CO}_{3}{ }^{2-}$ removal during the interaction of calcite with solutions with $[\mathrm{Pb}]_{\mathrm{i}}=1 \mathrm{mM}$ explained that the $\mathrm{pH}$ continued to slowly grow to approach values around 6.3 at the later stages of the interaction. The removal from the solution of $\mathrm{CO}_{3}{ }^{2-}$ ions was associated with the removal of the acidic $\mathrm{Pb}^{2+}$, which added up to the explain the $\mathrm{pH}$ evolution in the latter. The impact of $\mathrm{Pb}^{2+}$ removal on the $\mathrm{pH}$ evolution was much less significant in solutions $\left([\mathrm{Pb}]_{\mathrm{i}}=10 \mathrm{mM}\right)$ because in this case, the lead concentration remained very high during the whole duration of the experiments. Di Lorenzo et al. [71] 
pointed out that a small increase in the $\mathrm{pH}$ of a solution bearing both lead and carbonate ions translated into a much higher increase of the solution supersaturation with respect to hydrocerussite than with respect to cerussite. According to this, one would expect that hydrocerussite was formed in experiments conducted with an aqueous solution with $[\mathrm{Pb}]_{\mathrm{i}}=1 \mathrm{mM}$. However, this was not the case. The formation of hydrocerussite together with cerussite was observed when calcite interacted with solutions with $[\mathrm{Pb}]_{\mathrm{i}}=10 \mathrm{mM}$. However, despite the higher $\mathrm{pH}$ increase undergone by solutions with $[\mathrm{Pb}]_{\mathrm{i}}=1 \mathrm{mM}$ during the interaction, only cerussite formed in this case. A plausible explanation for this was that most $\mathrm{Pb}$ removal from solutions with $[\mathrm{Pb}]_{i}=1 \mathrm{mM}$ took place during the first $24 \mathrm{~h}$ of interaction, while $\mathrm{pH}$ solutions values remained below 6 . Moreover, the different stoichiometry of cerussite and hydrocerussite might also be a key factor that determines the influence of $\mathrm{pH}$ in the precipitation of these two lead-bearing carbonates, as pointed by Di Lorenzo et al. [71].

The kinetics of $\mathrm{Pb}$ removal is defined by the balance between the rate of the two reactions involved in the calcite dissolution-lead carbonate(s) precipitation loop. Both cerussite and hydrocerussite are very sparingly soluble phases $\left(\mathrm{pK}_{\text {cerussite }}=-13.13\right.$; $\left.\mathrm{pK}_{\text {hydrocerussite }}=-17.46\right)$ [72], which means that higher departures from equilibrium can result in the system during the interaction with calcite than during the interaction with gypsum [74,75]. In other words, the release of the same amount of $\mathrm{Pb}^{2+}$ ions to the solution led to far larger supersaturation changes with respect to lead carbonates than with respect to anglesite. However, in the time scale of the experiments in this work, precipitation of anglesite more efficiently removed $\mathrm{Pb}$ from a Pb-bearing solution interacting with gypsum than the formation of cerussite and hydrocerussite did when this solution interacted with calcite. Reaching slightly larger $\mathrm{Pb}$ removals through lead carbonate precipitation requires far longer interactions of $\mathrm{Pb}$-bearing solutions with calcite. The comparison of the variation of [Ca] in $\mathrm{Pb}$-bearing solutions during their interaction with gypsum or calcite illustrates the overwhelming difference between gypsum and calcite dissolution rates (Figures 2a and 3a), which has been contrasted by numerous macroscopic and microscopic studies $[65,66,68,71,76]$. Calcite dissolves much more slowly than gypsum. Consequently, the release of carbonate ions to the liquid phase that resulted from calcite dissolution took place much more slowly than the release of sulfate ions due to the dissolution of gypsum, which completely overbalanced the faster $\mathrm{Pb}$-removal that could be expected from the precipitation of more insoluble phases like cerussite and hydrocerussite compared to the precipitation of anglesite. Nevertheless, it is interesting to note that during the experiments of interaction between $\mathrm{Pb}$-solutions and calcite crystals in the work, more $\mathrm{Pb}^{2+}$ was removed from the solution than $\mathrm{Ca}^{2+}$ was released to it. Since calcite dissolution was congruent, this unbalance could imply that there was some $\mathrm{CO}_{2}$ atmospheric input leading to the formation of lead carbonate phase(s) and/or other Pb-uptake mechanisms than coprecipitation, such as $\mathrm{Pb}$ absorption and adsorption on calcite surfaces, were also operating and contributing to the net $\mathrm{Pb}$ removal.

From the results in this work, a scarce effectiveness of the interaction with calcite crystals to remove $\mathrm{Pb}$ from $\mathrm{Pb}$-bearing aqueous solutions can be concluded. This contrasts with the conclusions reported by Godelitsas et al. [65]. These authors reported a drop of the $\mathrm{Pb}$ concentration of solutions bearing 10 to $1000 \mathrm{mg} / \mathrm{L} \mathrm{Pb}$ to values below the experimental detection limit after $16 \mathrm{~h}$ of interaction with calcite crystals. The size of the calcite crystals used in both studies might be in the basis of the very different conclusions reached in both works. Godelitsas et al. [65] conducted interaction experiments with 100-200 micrometer-sized calcite crystals. Calcite crystals in this work were 3-4 mm-sized. The larger crystal surface area exposed to the interaction with the $\mathrm{Pb}$-bearing aqueous solution of the former may have resulted in a significantly faster release of calcium and carbonate ions to the liquid phase, which would have allowed for a faster mounting of the supersaturation of the $\mathrm{Pb}$-bearing solution with respect to lead carbonate phases. This faster supersaturation rate and reached supersaturation actual value could have facilitated the formation of significantly larger amounts of cerussite precipitates and, thereby, larger $\mathrm{Pb}$-removals than observed in this work. Moreover, the larger surface area of smaller-sized 
crystals could also have provided more sites for other sorption mechanisms to operate. These other sorption mechanisms could have further contributed to the larger balance of scavenged $\mathrm{Pb}$ reported by Godelitsas et al. [65].

\subsection{Effectiveness of Gypsum + Calcite as Pb Scavenger}

Regardless of $[\mathrm{Pb}]_{\mathrm{i}}$, the interaction of $\mathrm{Pb}$-bearing aqueous solutions with gypsum and calcite mixtures rapidly resulted to drops in $[\mathrm{Pb}]$ that closely paralleled those observed when the interaction took place only with gypsum (Figures $2 b$ and $3 b$ ). In the latter experiments, a $[\mathrm{Pb}] \sim 3 \mathrm{mg} / \mathrm{L}$ was reached after $48 \mathrm{~h}$ interaction regardless of $[\mathrm{Pb}]_{\mathrm{i}}$. In the case of calcite-gypsum mixtures, the same [Pb] was also reached after $48 \mathrm{~h}$ for solutions with $[\mathrm{Pb}]_{\mathrm{i}}=1 \mathrm{mM}$ and after $96 \mathrm{~h}$ when $[\mathrm{Pb}]_{\mathrm{i}}=10 \mathrm{mM}$.

However, the interaction with calcite-gypsum mixtures resulted in larger $\mathrm{Pb}$ removals than those attained in experiments using only gypsum (and, obviously, using only calcite) when longer interactions were considered. The minimum $[\mathrm{Pb}]$ reached through the interaction with gypsum and calcite mixtures in the time set of experiments in this work was $1.9 \mathrm{mg} / \mathrm{L}$ in a solution with $[\mathrm{Pb}]_{\mathrm{i}}=10 \mathrm{mM}, 0.7 \mathrm{mg} / \mathrm{L}$ in a solution with $[\mathrm{Pb}]_{\mathrm{i}}=1 \mathrm{mM}$, and after 7 days' interaction. The acidic conditions $(\mathrm{pH}<5.6)$ at the beginning of all the experiments promoted the dissolution of the pristine minerals. Gypsum dissolution was a transport-controlled reaction [77] which occurred at a significantly faster rate than the dissolution of calcite. This fact together with the relatively high solubility of gypsum explained that anglesite precipitation not only took place on gypsum surfaces but also occurred on calcite surfaces and in the bulk solution. Thus, the presence of anglesite crystals on the surface of both interacted gypsum and calcite crystals, together with the similarity between the $[\mathrm{Pb}]$ evolution curves in these experiments and those conducted with only gypsum crystals, supported the interpretation that the precipitation of anglesite was main reaction responsible for the fast $[\mathrm{Pb}]$ drop to approach $[\mathrm{Pb}] \sim 3 \mathrm{mg} / \mathrm{L}$, during the first 48 and $96 \mathrm{~h}$ in solutions with $[\mathrm{Pb}]_{\mathrm{i}}=1$ and $10 \mathrm{mM}$, respectively. However, as these $\mathrm{Pb}$-bearing solutions became equilibrated with gypsum and anglesite, anglesite precipitation could no longer occur. Further $\mathrm{Pb}$ removal mainly took place due to the precipitation of lead carbonates, most likely in the boundary layer around calcite crystals since these phases were only observed to form on calcite surfaces. During the interaction with gypsum and calcite mixtures, a similar $\mathrm{pH}$ evolution was observed in both $\mathrm{Pb}$-bearing aqueous solutions; that with $[\mathrm{Pb}]_{\mathrm{i}}=1 \mathrm{mM}$ and that with $[\mathrm{Pb}]_{\mathrm{i}}=10 \mathrm{mM}$ (Figure 1). Furthermore, in both cases $\mathrm{pH}$ values above 6 were reached after relatively short reactions times. This explained the formation of hydrocerussite on calcite surfaces regardless of $[\mathrm{Pb}]_{\mathrm{i}}$. This phase was not observed to form from solutions with $[\mathrm{Pb}]_{\mathrm{i}}=1 \mathrm{mM}$ that interacted only with calcite, whose $\mathrm{pH}$ remained below 6 at the beginning of the experiment, as discussed in Section 4.2. Once lead carbonate precipitation became the main $\mathrm{Pb}$ removal operating mechanism, $\mathrm{Pb}$ removal slowed down. This slowdown was observed at latter stages of the interaction, when the slow calcite dissolution became the rate limiting process defining the kinetics of the calcite dissolution-lead carbonate precipitation feedback loop. This slowdown that occurred was more marked and occurred earlier when gypsum and calcite mixtures interacted with solutions with $[\mathrm{Pb}]_{\mathrm{i}}=10 \mathrm{mM}$. A possible explanation for this slowdown could relate to significant $\mathrm{Pb}$ adsorption taking place on calcite surfaces that resulted in calcite dissolution inhibition.

\section{Conclusions}

Under the mildly acidic conditions in this work, the interaction of aqueous solutions bearing $10 \mathrm{mM} \geq[\mathrm{Pb}] \geq 1 \mathrm{mM}$ with gypsum, calcite, or mixtures of crystals or 50:50 mixtures of gypsum and calcite crystals resulted in a $\mathrm{Pb}$ removal that could be fast and extensive when gypsum was present in the system, but progressed at a comparably extremely slow rate in the absence of this phase. Regardless of its kinetics, in all the systems studied coprecipitation of $\mathrm{Pb}$-bearing mineral phases was the main mechanism of $\mathrm{Pb}$ removal. These $\mathrm{Pb}$-bearing phases formed as a result of the reaction between dissolved $\mathrm{Pb}$ and 
$\mathrm{SO}_{4}{ }^{2-}$ and $/$ or $\mathrm{CO}_{3}{ }^{2-}$ ions released during the dissolution of the primary phases, gypsum, and/or calcite. The early formation of anglesite $\left(\mathrm{PbSO}_{4}\right)$ both in the bulk and on the surface of crystals of the primary phase(s) led to a rapid drop of $[\mathrm{Pb}]$ to $\sim 3 \mathrm{mg} / \mathrm{L}$. This value is well above the accepted maximum $[\mathrm{Pb}]$ for drinking water. No further $\mathrm{Pb}$ removal was achieved through interaction of $\mathrm{Pb}$-bearing solutions only with gypsum, no matter the duration of the interaction. Interaction of $\mathrm{Pb}$-bearing solutions with calcite resulted in the formation of cerussite $\left(\mathrm{PbCO}_{3}\right)$ and hydrocerussite $\left(\mathrm{Pb}_{3}\left(\mathrm{CO}_{3}\right)_{2}(\mathrm{OH})_{2}\right)$. The sluggish kinetics of calcite dissolution made $\mathrm{Pb}$ removal through precipitation of lead carbonates a very slow process, which resulted very inefficiently compared to the precipitation of anglesite, at least within the time set of experiments in this study. Interestingly, the simultaneous interaction of $\mathrm{Pb}$-bearing aqueous solutions with crystals of both phases and gypsum-calcite crystals resulted in $\mathrm{Pb}$ removals that, depending on $[\mathrm{Pb}]_{i}$, were from as much as up to 5 times larger than those attained through interaction only with gypsum, and up to 500 times larger than those attained when solutions only interact with calcite. Further exploration of $\mathrm{Pb}$ removal from aqueous solutions simultaneously in contact with gypsum and calcite could help to shed light on the fate of lead in sedimentary basins as well as help to design more efficient strategies for decontaminating $\mathrm{Pb}$-polluted waters through the integration of sequences of co-precipitation processes.

Author Contributions: Conceptualization, L.F.-D., A.J. and A.R.L.; methodology, A.J. and A.R.L.; software, A.R.L.; validation, L.F.-D., A.J. and A.R.L.; formal analysis, A.R.L.; investigation, L.F.-D., A.J. and A.R.L.; data curation, A.R.L.; writing-original draft preparation, L.F.-D. and A.R.L.; writingreview and editing, L.F.-D., A.J. and A.R.L.; supervision, A.J. and L.F.-D.; funding acquisition, L.F.-D. and A.J. All authors have read and agreed to the published version of the manuscript.

Funding: This study was supported by the Ministry of Science, Innovation and Universities (CIENCIA) (Spain) under projects CGL2016-77138-C2-1-P and CGL2016-77138-C2-2-P. A.R.L. acknowledges funding through contract BES-2017-081759 from the Spanish CIENCIA.

Data Availability Statement: The data presented in this study are contained within the article.

Conflicts of Interest: The authors declare no conflict of interest.

\section{References}

1. Bradl, H. Heavy Metals in the Environment: Origin, Interaction and Remediation; Elsevier: Amsterdam, The Netherlands, 2005; Volume 6, ISBN 0-08-045500-X.

2. Nriagu, J.O.; Pacyna, J.M. Quantitative assessment of worldwide contamination of air, water and soils by trace metals. Nat. Cell Biol. 1988, 333, 134-139. [CrossRef] [PubMed]

3. Thevenon, F.; Graham, N.D.; Chiaradia, M.; Arpagaus, P.; Wildi, W.; Pote-Wembonyama, J. Local to regional scale industrial heavy metal pollution recorded in sediments of large freshwater lakes in central Europe (lakes Geneva and Lucerne) over the last centuries. Sci. Total Environ. 2011, 412, 239-247. [CrossRef] [PubMed]

4. Zachara, J.; Cowan, C.; Resch, C. Sorption of divalent metals on calcite. Geochim. Cosmochim. Acta 1991, 55, 1549-1562. [CrossRef]

5. Khan, A.E.; Ireson, A.; Kovats, S.; Mojumder, S.K.; Khusru, A.; Rahman, A.; Vineis, P. Drinking Water Salinity and Maternal Health in Coastal Bangladesh: Implications of Climate Change. Environ. Health Perspect. 2011, 119, 1328-1332. [CrossRef]

6. Charlesworth, S.; De Miguel, E.; Ordóñez, A. A review of the distribution of particulate trace elements in urban terrestrial environments and its application to considerations of risk. Environ. Geochem. Health 2011, 33, 103-123. [CrossRef]

7. Von Storch, H.; Hagner, C. Controlling Lead Concentrations in Human Blood by Regulating the Use of Lead in Gasoline. Ambio A J. Hum. Environ. 2004, 33, 126-132. [CrossRef]

8. Chattopadhyay, G.; Lin, K.C.-P.; Feitz, A. Household dust metal levels in the Sydney metropolitan area. Environ. Res. 2003, 93, 301-307. [CrossRef]

9. Al Hejami, A.; Davis, M.; Prete, D.; Lu, J.; Wang, S. Heavy metals in indoor settled dusts in Toronto, Canada. Sci. Total Environ. 2020, 703, 134895. [CrossRef] [PubMed]

10. Jang, Y.-C.; Townsend, T.G. Leaching of Lead from Computer Printed Wire Boards and Cathode Ray Tubes by Municipal Solid Waste Landfill Leachates. Environ. Sci. Technol. 2003, 37, 4778-4784. [CrossRef]

11. Obeng-Gyasi, E. Sources of lead exposure in various countries. Rev. Environ. Health 2019, 34, 25-34. [CrossRef]

12. Tukker, A.; Buist, H.; Van Oers, L.; Van Der Voet, E. Risks to health and environment of the use of lead in products in the EU. Resour. Conserv. Recycl. 2006, 49, 89-109. [CrossRef]

13. Audry, S.; Schäfer, J.; Blanc, G.; Jouanneau, J.M. Fifty-year sedimentary record of heavy metal pollution $(\mathrm{Cd}, \mathrm{Zn}, \mathrm{Cu}, \mathrm{Pb}) \mathrm{in}$ the Lot River reservoirs (France). Environ. Pollut. 2004, 132, 413-426. [CrossRef] [PubMed] 
14. Khanam, R.; Kumar, A.; Nayak, A.K.; Shahid; Tripathi, R.; Vijayakumar, S.; Bhaduri, D.; Kumar, U.; Mohanty, S.; Panneerselvam, P.; et al. Metal(loid)s (As, $\mathrm{Hg}$, Se, $\mathrm{Pb}$ and $\mathrm{Cd}$ ) in paddy soil: Bioavailability and potential risk to human health. Sci. Total Environ. 2020, 699, 134330. [CrossRef] [PubMed]

15. Mapanda, F.; Mangwayana, E.; Nyamangara, J.; Giller, K. The effect of long-term irrigation using wastewater on heavy metal contents of soils under vegetables in Harare, Zimbabwe. Agric. Ecosyst. Environ. 2005, 107, 151-165. [CrossRef]

16. Oliver, M. Soil and human health: A review. Eur. J. Soil Sci. 1997, 48, 573-592. [CrossRef]

17. Zhuang, P.; McBride, M.B.; Xia, H.; Li, N.; Li, Z. Health risk from heavy metals via consumption of food crops in the vicinity of Dabaoshan mine, South China. Sci. Total Environ. 2009, 407, 1551-1561. [CrossRef] [PubMed]

18. Li, Z.; Ma, Z.; Van Der Kuijp, T.J.; Yuan, Z.; Huang, L. A review of soil heavy metal pollution from mines in China: Pollution and health risk assessment. Sci. Total Environ. 2014, 468, 843-853. [CrossRef]

19. Rodríguez, L.; Ruiz, E.; Alonso-Azcárate, J.; Rincón, J. Heavy metal distribution and chemical speciation in tailings and soils around a Pb-Zn mine in Spain. J. Environ. Manag. 2009, 90, 1106-1116. [CrossRef]

20. Simon, M.; Ortiz, I.; García, I.; Fernández, E.; Dorronsoro, C.; Aguilar, J. Pollution of soils by the toxic spill of a pyrite mine (Aznalcollar, Spain). Sci. Total Environ. 1999, 242, 105-115. [CrossRef]

21. Laidlaw, M.A.S.; Filippelli, G.M.; Sadler, R.C.; Gonzales, C.R.; Ball, A.S.; Mielke, H.W. Children's Blood Lead Seasonality in Flint, Michigan (USA), and Soil-Sourced Lead Hazard Risks. Int. J. Environ. Res. Public Health 2016, 13, 358. [CrossRef]

22. Jung, M.C.; Thornton, I. Environmental contamination and seasonal variation of metals in soils, plants and waters in the paddy fields around a Pb-Zn mine in Korea. Sci. Total Environ. 1997, 198, 105-121. [CrossRef]

23. Luo, X.-S.; Ding, J.; Xu, B.; Wang, Y.-J.; Li, H.-B.; Yu, S. Incorporating bioaccessibility into human health risk assessments of heavy metals in urban park soils. Sci. Total Environ. 2012, 424, 88-96. [CrossRef] [PubMed]

24. Ryan, P.B.; Huet, N.; MacIntosh, D.L. Longitudinal investigation of exposure to arsenic, cadmium, and lead in drinking water. Environ. Health Perspect. 2000, 108, 731-735. [CrossRef] [PubMed]

25. Tong, S.L.; Von Schirnding, Y.E.; Prapamontol, T. Environmental lead exposure: A public health problem of global dimensions. Bull. World Health Organ. 2000, 78, 1068-1077. [PubMed]

26. Zheng, N.; Wang, Q.; Zheng, D. Health risk of $\mathrm{Hg}, \mathrm{Pb}, \mathrm{Cd}, \mathrm{Zn}$, and $\mathrm{Cu}$ to the inhabitants around Huludao Zinc Plant in China via consumption of vegetables. Sci. Total Environ. 2007, 383, 81-89. [CrossRef] [PubMed]

27. Njati, S.Y.; Maguta, M.M. Lead-based paints and children's PVC toys are potential sources of domestic lead poisoning-A review. Environ. Pollut. 2019, 249, 1091-1105. [CrossRef] [PubMed]

28. Piekut, A.; Gut, K.; Ćwielag-Drabek, M.; Domagalska, J.; Marchwińska-Wyrwał, E. The relationship between children's nonnutrient exposure to cadmium, lead and zinc and the location of recreational areas-Based on the Upper Silesia region case (Poland). Chemosphere 2019, 223, 544-550. [CrossRef]

29. Pirkle, J.L.; Kaufmann, R.B.; Brody, D.J.; Hickman, T.; Gunter, E.W.; Paschal, D.C. Exposure of the U.S. population to lead, 1991-1994. Environ. Health Perspect. 1998, 106, 745-750. [CrossRef]

30. Zheng, N.; Liu, J.; Wang, Q.; Liang, Z. Health risk assessment of heavy metal exposure to street dust in the zinc smelting district, Northeast of China. Sci. Total Environ. 2010, 408, 726-733. [CrossRef]

31. Ma, Q.Y.; Traina, S.J.; Logan, T.J.; Ryan, J.A. In Situ lead immobilization by apatite. Environ. Sci. Technol. 1993, 27, 1803-1810. [CrossRef]

32. Traina, S.J.; Laperche, V. Contaminant bioavailability in soils, sediments, and aquatic environments. Proc. Natl. Acad. Sci. USA 1999, 96, 3365-3371. [CrossRef] [PubMed]

33. Warren, J.K. Evaporites: Sediments, Resources and Hydrocarbons; Springer: Berlin, Germany, 2006; ISBN 3-540-32344-9.

34. Sposito, G. Distinguishing Adsorption from Surface Precipitation; American Chemical Society (ACS): Washington, DC, USA, 1987; pp. 217-228.

35. Prieto, M.; Cubillas, P.; Fernández-Gonzalez, Á. Uptake of dissolved Cd by biogenic and abiogenic aragonite: A comparison with sorption onto calcite. Geochim. Cosmochim. Acta 2003, 67, 3859-3869. [CrossRef]

36. Brown, G.; Parks, G.; O’Day, P. Mineral Surfaces; Vaughan, D.J., Pattrick, R.A.D., Eds.; Chapman \& Hall: New York, NY, USA, 1995.

37. Pérez-Garrido, C.; Fernández-Díaz, L.; Pina, C.M.; Prieto, M. In Situ AFM observations of the interaction between calcite surfaces and Cd-bearing aqueous solutions. Surf. Sci. 2007, 601, 5499-5509. [CrossRef]

38. Dyer, A. Mineral Surfaces; Vaughan, D.J., Pattrick, R.A.D., Eds.; Chapman Hall: London, UK, 1995; pp. $333-354$.

39. Putnis, A.; Putnis, C.V. The mechanism of reequilibration of solids in the presence of a fluid phase. J. Solid State Chem. 2007, 180, 1783-1786. [CrossRef]

40. Putnis, A. Mineral Replacement Reactions. Rev. Miner. Geochem. 2009, 70, 87-124. [CrossRef]

41. Agudo, E.R.; Putnis, C.V.; Putnis, A. Coupled dissolution and precipitation at mineral-fluid interfaces. Chem. Geol. 2014, 383, 132-146. [CrossRef]

42. Pollok, K.; Putnis, C.V.; Putnis, A. Mineral replacement reactions in solid solution-aqueous solution systems: Volume changes, reactions paths and end-points using the example of model salt systems. Am. J. Sci. 2011, 311, 211-236. [CrossRef]

43. Putnis, C.V.; Geisler, T.; Schmid-Beurmann, P.; Stephan, T.; Giampaolo, C. An experimental study of the replacement of leucite by analcime. Am. Miner. 2007, 92, 19-26. [CrossRef]

44. Agudo, E.R.; Putnis, C.V.; Rodriguez-Navarro, C.; Putnis, A. Mechanism of leached layer formation during chemical weathering of silicate minerals. Geology 2012, 40, 947-950. [CrossRef] 
45. Ruiz-Agudo, E.; King, H.E.; Patiño-López, L.D.; Putnis, C.V.; Geisler, T.; Rodriguez-Navarro, C.; Putnis, A. Control of silicate weathering by interface-coupled dissolution-precipitation processes at the mineral-solution interface. Geology 2016, 44, 567-570. [CrossRef]

46. Altree-Williams, A.; Pring, A.; Ngothai, Y.; Brugger, J. Textural and compositional complexities resulting from coupled dissolutionreprecipitation reactions in geomaterials. Earth-Sci. Rev. 2015, 150, 628-651. [CrossRef]

47. Altree-Williams, A.; Brugger, J.; Pring, A.; Bedrikovetsky, P. Coupled reactive flow and dissolution with changing reactive surface and porosity. Chem. Eng. Sci. 2019, 206, 289-304. [CrossRef]

48. Prieto, M.; Astilleros, J.M.; Fernández-Díaz, L. Environmental Remediation by Crystallization of Solid Solutions. Elements 2013, 9 , 195-201. [CrossRef]

49. Morales, J.; Astilleros, J.M.; Jiménez, A.; Göttlicher, J.; Steininger, R.; Fernández-Díaz, L. Uptake of dissolved lead by anhydrite surfaces. Appl. Geochem. 2014, 40, 89-96. [CrossRef]

50. Wang, L.; Putnis, C.V.; Ruiz-Agudo, E.; King, H.E.; Putnis, A. Coupled Dissolution and Precipitation at the Cerussite-Phosphate Solution Interface: Implications for Immobilization of Lead in Soils. Environ. Sci. Technol. 2013, 47, 13502-13510. [CrossRef]

51. Pina, C.; Fernández-Díaz, L.; Prieto, M.; Putnis, A. In Situ atomic force microscope observations of a dissolution-crystallisation reaction: The phosgenite-cerussite transformation. Geochim. Cosmochim. Acta 2000, 64, 215-221. [CrossRef]

52. Roncal-Herrero, T.; Astilleros, J.M.; Bots, P.; Rodríguez-Blanco, J.D.; Prieto, M.; Benning, L.G.; Fernández-Díaz, L. Reaction pathways and textural aspects of the replacement of anhydrite by calcite at $25^{\circ} \mathrm{C}$. Am. Miner. 2017, 102, 1270-1278. [CrossRef]

53. Sánchez-Pastor, N.; Pina, C.M.; Fernández-Díaz, L. A combined in situ AFM and SEM study of the interaction between celestite (001) surfaces and carbonate-bearing aqueous solutions. Surf. Sci. 2007, 601, 2973-2982. [CrossRef]

54. Pérez-Garrido, C.; Astilleros, J.M.; Fernández-Díaz, L.; Prieto, M. In Situ AFM study of the interaction between calcite $\left\{101^{-} 4\right\}$ surfaces and supersaturated $\mathrm{Mn}^{2+}-\mathrm{CO}_{3}{ }^{2-}$ aqueous solutions. J. Cryst. Growth 2009, 311, 4730-4739. [CrossRef]

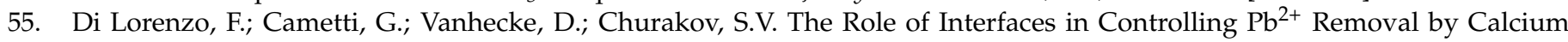
Carbonate Minerals. Cryst. Growth Des. 2020, 20, 6157-6169. [CrossRef]

56. Wang, L.; Agudo, E.R.; Putnis, C.V.; Menneken, M.; Putnis, A. Kinetics of Calcium Phosphate Nucleation and Growth on Calcite: Implications for Predicting the Fate of Dissolved Phosphate Species in Alkaline Soils. Environ. Sci. Technol. 2012, 46, 834-842. [CrossRef] [PubMed]

57. Wang, L.; Li, S.; Agudo, E.R.; Putnis, C.V.; Putnis, A. Posner's cluster revisited: Direct imaging of nucleation and growth of nanoscale calcium phosphate clusters at the calcite-water interface. CrystEngComm 2012, 14, 6252-6256. [CrossRef]

58. Guren, M.G.; Putnis, C.V.; Montes-Hernandez, G.; King, H.E.; Renard, F. Direct imaging of coupled dissolution-precipitation and growth processes on calcite exposed to chromium-rich fluids. Chem. Geol. 2020, 552, 119770. [CrossRef]

59. Pérez, P.F.; Astilleros, J.M.; Fernández-Díaz, L. The Formation of Barite and Celestite through the Replacement of Gypsum. Minerals 2020, 10, 189. [CrossRef]

60. Morales, J.; Astilleros, J.M.; Fernández-Díaz, L.; Álvarez-Lloret, P.; Jiménez, A. Anglesite $\left(\mathrm{PbSO}_{4}\right)$ epitactic overgrowths and substrate-induced twinning on anhydrite $\left(\mathrm{CaSO}_{4}\right)$ cleavage surfaces. J. Cryst. Growth 2013, 380, 130-137. [CrossRef]

61. Rodríguez, J.D.; Jiménez, A.; Prieto, M.; Torre, L.; García-Granda, S. Interaction of gypsum with As (V)-bearing aqueous solutions: Surface precipitation of guerinite, sainfeldite, and $\mathrm{Ca}_{2} \mathrm{NaH}\left(\mathrm{AsO}_{4}\right)_{2} 6 \mathrm{H}_{2} \mathrm{O}$, a synthetic arsenate. Am. Miner. 2008, 93, 928-939. [CrossRef]

62. Pinto, A.J.; Agudo, E.R.; Putnis, C.V.; Putnis, A.; Jiménez, A.; Prieto, M. AFM study of the epitaxial growth of brushite $\left(\mathrm{CaHPO}_{4}\right.$ $2 \mathrm{H}_{2} \mathrm{O}$ ) on gypsum cleavage surfaces. Am. Miner. 2010, 95, 1747-1757. [CrossRef]

63. Pinto, A.J.; Jimenez, A.; Prieto, M. Interaction of phosphate-bearing solutions with gypsum: Epitaxy and induced twinning of brushite $\left(\mathrm{CaHPO}_{4} 2 \mathrm{H}_{2} \mathrm{O}\right)$ on the gypsum cleavage surface. Am. Miner. 2009, 94, 313-322. [CrossRef]

64. Yu, L.; Daniels, L.M.; Mulders, J.J.; Saldi, G.D.; Harrison, A.L.; Liu, L.; Oelkers, E.H. An experimental study of gypsum dissolution coupled to $\mathrm{CaCO}_{3}$ precipitation and its application to carbon storage. Chem. Geol. 2019, 525, 447-461. [CrossRef]

65. Godelitsas, A.; Astilleros, J.M.; Hallam, K.; Harissopoulos, S.; Putnis, A.; Harissopulos, S. Interaction of Calcium Carbonates with Lead in Aqueous Solutions. Environ. Sci. Technol. 2003, 37, 3351-3360. [CrossRef]

66. Elzinga, E.J.; Rouff, A.A.; Reeder, R.J. The long-term fate of $\mathrm{Cu}^{2+}, \mathrm{Zn}^{2+}$, and $\mathrm{Pb}^{2+}$ adsorption complexes at the calcite surface: An X-ray absorption spectroscopy study. Geochim. Cosmochim. Acta 2006, 70, 2715-2725. [CrossRef]

67. Rangel-Porras, G.; García-Magno, J.; González-Muñoz, M. Lead and cadmium immobilization on calcitic limestone materials. Desalination 2010, 262, 1-10. [CrossRef]

68. Astilleros, J.; Godelitsas, A.; Rodriguez-Blanco, J.D.; Fernández-Díaz, L.; Prieto, M.; Lagoyannis, A.; Harissopulos, S. Interaction of gypsum with lead in aqueous solutions. Appl. Geochem. 2010, 25, 1008-1016. [CrossRef]

69. Rouff, A.A.; Elzinga, E.J.; Reeder, R.J.; Fisher, N.S. The Effect of Aging and pH on Pb(II) Sorption Processes at the Calcite-Water Interface. Environ. Sci. Technol. 2006, 40, 1792-1798. [CrossRef] [PubMed]

70. Sturchio, N.C.; Chiarello, R.P.; Cheng, L.; Lyman, P.F.; Bedzyk, M.J.; Qian, Y.; You, H.; Yee, D.; Geissbuhler, P.; Sorensen, L.B.; et al. Lead adsorption at the calcite-water interface: Synchrotron X-ray standing wave and X-ray reflectivity studies. Geochim. Cosmochim. Acta 1997, 61, 251-263. [CrossRef]

71. Di Lorenzo, F.; Ruiz-Agudo, C.; Churakov, S.V. The key effects of polymorphism during PbII uptake by calcite and aragonite. CrystEngComm 2019, 21, 6145-6155. [CrossRef] 
72. Parkhurst, D.L.; Appelo, C. Description of input and examples for PHREEQC version 3: A computer program for speciation, batch-reaction, one-dimensional transport, and inverse geochemical calculations. Tech. Methods 2013. [CrossRef]

73. Gray, N.F. Drinking Water Quality: Problems and Solutions; John Wiley \& Sons: Chichester, UK, 2008; ISBN 1-139-47041-8.

74. Prieto, M.; Putnis, A.; Fernández-Díaz, L.; López-Andrés, S. Metastability in diffusing-reacting systems. J. Cryst. Growth 1994, 142, 225-235. [CrossRef]

75. Prieto, M.; Putnis, A.; Fernández-Díaz, L. Crystallization of solid solutions from aqueous solutions in a porous medium: Zoning in (Ba,Sr)SO 4 . Geol. Mag. 1993, 130, 289-299. [CrossRef]

76. Yuan, K.; Lee, S.S.; De Andrade, V.; Sturchio, N.C.; Fenter, P. Replacement of Calcite $\left(\mathrm{CaCO}_{3}\right)$ by Cerussite $\left(\mathrm{PbCO}_{3}\right)$. Environ. Sci. Technol. 2016, 50, 12984-12991. [CrossRef]

77. Berner, R.A. Early Diagenesis: A Theoretical Approach; Princeton University Press: Princeton, NJ, USA, 1980; ISBN 0-691-08260-X. 